\title{
Metabolism-Disrupting Chemicals and the Constitutive Androstane Receptor CAR
}

\author{
Jenni Küblbeck ${ }^{1,2}$, Jonna Niskanen ${ }^{2}\left(\mathbb{D}\right.$ and Paavo Honkakoski ${ }^{2,3, *(\mathbb{C}}$ \\ 1 A.I. Virtanen Institute for Molecular Sciences, University of Eastern Finland, P.O. Box 1627, \\ FI-70210 Kuopio, Finland; jenni.kublbeck@uef.fi \\ 2 School of Pharmacy, University of Eastern Finland, P.O. Box 1627, FI-70210 Kuopio, Finland; \\ jonna.niskanen@uef.fi \\ 3 Division of Pharmacotherapy and Experimental Therapeutics, Eshelman School of Pharmacy, \\ University of North Carolina at Chapel Hill, Campus Box 7569, Chapel Hill, NC 27599-7569, USA \\ * Correspondence: paavo.honkakoski@uef.fi; Tel.: +35-840-355-2490
}

Received: 15 September 2020; Accepted: 13 October 2020; Published: 15 October 2020

\begin{abstract}
During the last two decades, the constitutive androstane receptor (CAR; NR1I3) has emerged as a master activator of drug- and xenobiotic-metabolizing enzymes and transporters that govern the clearance of both exogenous and endogenous small molecules. Recent studies indicate that CAR participates, together with other nuclear receptors (NRs) and transcription factors, in regulation of hepatic glucose and lipid metabolism, hepatocyte communication, proliferation and toxicity, and liver tumor development in rodents. Endocrine-disrupting chemicals (EDCs) constitute a wide range of persistent organic compounds that have been associated with aberrations of hormone-dependent physiological processes. Their adverse health effects include metabolic alterations such as diabetes, obesity, and fatty liver disease in animal models and humans exposed to EDCs. As numerous xenobiotics can activate CAR, its role in EDC-elicited adverse metabolic effects has gained much interest. Here, we review the key features and mechanisms of CAR as a xenobiotic-sensing receptor, species differences and selectivity of CAR ligands, contribution of CAR to regulation hepatic metabolism, and evidence for CAR-dependent EDC action therein.
\end{abstract}

Keywords: endocrine disruption; metabolic disruptors; constitutive androstane receptor; NR1I3; glucose metabolism; lipid metabolism

\section{Introduction}

Endocrine-disrupting chemicals (EDCs) are natural or synthetic compounds that alter functions of the endocrine system and as a consequence, cause adverse health effects in an intact organism or its progeny or subpopulations, e.g., via interactions with nuclear receptors (NRs) and other targets of endogenous hormones and other signaling molecules [1,2]. The synthetic EDCs are structurally diverse, often lipophilic substances capable of bioaccumulation (persistent organic pollutants). Examples include plasticizers, pesticides, fungicides, and various polyhalogenated organic compounds present in consumer products, environment, or exposures from industrial sources [1]. EDCs may interfere with regulation of body homeostasis by mimicking, suppressing, or altering the normal physiological responses. These adverse actions can be mediated by e.g., direct agonism/antagonism of these receptors, indirect effects via modulation of synthesis or clearance of endogenous receptor ligands, interference of the downstream signaling pathways or the endocrine feedback systems between tissues or through epigenetic changes that dysregulate the hormonal signaling pathways and may be transmitted to the next progeny [3]. Due to the high degree of sequence similarity and conservation of signaling pathways for many receptors across species, EDCs can exert their effects in both wildlife 
and humans. As the same receptors are often critical for the growth, maturation, and maintenance of endocrine tissues, the effects of EDCs are thought to be especially problematic for developing individuals. The adverse effects on birth outcomes, sexually determined physiological characteristics, reproductive health, and neuroendocrine functions in humans have been well documented in epidemiological studies [1,4].

Recently, EDCs have been linked to disturbances in metabolic processes such as type 2 diabetes (T2D), metabolic syndrome, obesity, and non-alcoholic fatty liver disease (NAFLD) that are increasingly prevalent in Western societies and among the younger populations. Several mechanisms proposed to underlie these aberrations include dysregulation of food and energy intake at the gut-brain axis, interference of normal energy consumption, abnormal storage of energy in adipose tissue (obesity) and the liver (steatosis), and unbalances in handling of energy sources between tissues [5,6]. Several NRs expressed in the liver coordinate the hepatic glucose, lipid bile acid and energy metabolism and their functions can be modulated by EDCs (Table 1.) [7,8]. Among these NRs, the peroxisome proliferator-activated receptors (PPARs), pregnane $X$ receptor (PXR), and constitutive androstane receptor (CAR) seem to play central roles in glucose and fatty acid metabolism.

Here, we review the characteristics of CAR, mechanisms by which CAR is involved in metabolic processes, and finally, the effects of metabolism-disrupting chemicals on CAR activity and signaling. To this end, we selected the currently known EDC classes from existing literature since the year 2000 with an emphasis on compounds that have been associated with metabolic disruption. We then extended our literature searches on each EDC class and their prototypical compounds to identify articles showing interaction with CAR in a variety of in vitro, cellular, and animal models. Targeted searches based on reference lists, available Toxcast data, and other relevant NRs were also conducted. Thus, EDCs that interfere only with e.g., reproductive system and do not interact with CAR are not included here. 
Table 1. Modulation of nuclear receptor activities by CAR-relevant EDCs.

\begin{tabular}{|c|c|c|c|c|c|c|c|c|c|c|c|c|c|c|c|c|c|c|}
\hline \multirow{3}{*}{ EDC Group } & \multicolumn{18}{|c|}{ Nuclear Receptors Relevant for Energy Metabolism [9,10] } \\
\hline & \multicolumn{2}{|c|}{ CAR } & \multicolumn{2}{|c|}{ PXR } & \multicolumn{2}{|c|}{ PPARs } & \multicolumn{2}{|c|}{ LXRs } & \multicolumn{2}{|c|}{ TR } & \multicolumn{2}{|c|}{ ERRs } & \multirow{2}{*}{$\begin{array}{c}\text { FXR } \\
\mathrm{h}\end{array}$} & \multirow{2}{*}{$\frac{\mathrm{RXR}}{\mathrm{h}}$} & \multirow{2}{*}{$\frac{\text { RAR }}{\mathrm{h}}$} & \multirow{2}{*}{$\begin{array}{c}\text { VDR } \\
\mathrm{h}\end{array}$} & \multirow{2}{*}{$\begin{array}{c}\text { GR } \\
h\end{array}$} & \multirow{2}{*}{$\begin{array}{c}\text { MR } \\
h\end{array}$} \\
\hline & $\mathbf{h}$ & $\mathbf{r}$ & $\mathrm{h}$ & $\mathbf{r}$ & $\mathbf{h}$ & $\mathbf{r}$ & $\mathrm{h}$ & $\mathbf{r}$ & $\mathbf{h}$ & $\mathbf{r}$ & $\mathrm{h}$ & $\mathbf{r}$ & & & & & & \\
\hline Alkylphenols & $\uparrow[11]$ & $\uparrow[12]$ & $\uparrow[13]$ & $\uparrow[14]$ & & & & & & & & & & $\begin{array}{c}\downarrow \\
{[15]}\end{array}$ & & & & \\
\hline Bisphenols & $\begin{array}{c}\uparrow \downarrow \\
{[11,16]}\end{array}$ & & $\begin{array}{c}\uparrow \\
{[16,17]}\end{array}$ & & $\begin{array}{c}\uparrow \\
{[18,19]}\end{array}$ & $\uparrow[18]$ & & $\begin{array}{c}\uparrow \\
{[20]}\end{array}$ & $\downarrow[21]$ & $\begin{array}{c}\downarrow \\
{[22]}\end{array}$ & $\begin{array}{c}\uparrow \\
{[17]}\end{array}$ & & & & & & $\begin{array}{c}\downarrow \\
{[16,17]}\end{array}$ & $\downarrow[17]$ \\
\hline Phthalates & $\begin{array}{c}\uparrow \uparrow \\
{[11,23-25]}\end{array}$ & $\begin{array}{c}\uparrow \\
{[11,23-25]}\end{array}$ & $\begin{array}{c}\uparrow \\
{[11,23-25]}\end{array}$ & $\begin{array}{c}\uparrow \\
{[11,23-25]}\end{array}$ & $\uparrow[23]$ & $\uparrow[23]$ & $\uparrow[26]$ & & & $\begin{array}{c}\downarrow \\
{[27]}\end{array}$ & & & & & & & & \\
\hline PFAS & $\uparrow[28]$ & $\uparrow[28]$ & & & $\uparrow[29]$ & $\uparrow[30]$ & & & & & & & & & & & & \\
\hline $\begin{array}{c}\text { Flame } \\
\text { retardants }\end{array}$ & $\begin{array}{c}\uparrow \\
{[31-33]}\end{array}$ & $\begin{array}{c}\uparrow \\
{[31-33]}\end{array}$ & $\uparrow[31]$ & $\uparrow[31]$ & $\begin{array}{c}\uparrow \\
{[34,35]}\end{array}$ & & $\uparrow[26]$ & & $\begin{array}{c}\downarrow \\
{[36,37]}\end{array}$ & & $\begin{array}{c}\downarrow \\
{[38]}\end{array}$ & & & $\begin{array}{c}\uparrow \\
{[39]}\end{array}$ & & $\begin{array}{c}\uparrow \\
{[39]}\end{array}$ & $\uparrow[39]$ & \\
\hline PCBs & $\begin{array}{c}\uparrow \\
{[40]}\end{array}$ & $\begin{array}{c}\uparrow \\
{[41]}\end{array}$ & $\begin{array}{c}\uparrow \\
{[40]}\end{array}$ & $\begin{array}{c}\uparrow \\
{[41]}\end{array}$ & & & & & $\downarrow[42]$ & & & & & & & & $\downarrow[43]$ & \\
\hline Pesticides & $\begin{array}{c}\uparrow \\
{[44,45]}\end{array}$ & $\begin{array}{c}\uparrow \\
{[44]}\end{array}$ & $\begin{array}{c}\uparrow \\
{[44-46]}\end{array}$ & $\uparrow[44]$ & $\uparrow[47]$ & $\uparrow[48]$ & & & $\downarrow[49]$ & & $\begin{array}{c}\downarrow \\
{[50]}\end{array}$ & $\begin{array}{c}\downarrow \\
{[50]}\end{array}$ & $\begin{array}{c}\downarrow \\
{[51]}\end{array}$ & & $\begin{array}{c}\uparrow \\
{[52]}\end{array}$ & & $\begin{array}{c}\downarrow \\
{[43,53]}\end{array}$ & $\begin{array}{c}\downarrow \\
{[43,54]}\end{array}$ \\
\hline Fungicides & $\begin{array}{c}\uparrow \downarrow \\
{[55-57]}\end{array}$ & $\begin{array}{c}\uparrow \downarrow \\
{[55-57]}\end{array}$ & $\begin{array}{c}\uparrow \\
{[55,56]}\end{array}$ & $\begin{array}{c}\uparrow \\
{[55,56]}\end{array}$ & & & & & & & & & & & & & $\downarrow[58]$ & $\downarrow[59]$ \\
\hline Parabens & & $\uparrow \downarrow[60]$ & $\uparrow[60]$ & $\downarrow[60]$ & $\uparrow[61]$ & $\uparrow[60]$ & & & & & & & & & & & $\uparrow[61]$ & \\
\hline Triclosan & $\uparrow \downarrow[62]$ & $\downarrow[62]$ & $\uparrow[62]$ & & $\downarrow[63]$ & $\begin{array}{c}\uparrow \\
{[63,64]}\end{array}$ & & & & & & & & & & & & \\
\hline $\begin{array}{c}\text { THMs, } \\
\text { natural } \\
\text { compounds }\end{array}$ & $\begin{array}{c}\uparrow \\
{[65-67]}\end{array}$ & $\uparrow[67]$ & $\begin{array}{c}\uparrow \\
{[67,68]}\end{array}$ & $\uparrow[67]$ & $\begin{array}{c}\uparrow \downarrow \\
{[51,69]}\end{array}$ & & $\begin{array}{c}\uparrow \downarrow \\
{[70]}\end{array}$ & & & & $\begin{array}{c}\uparrow \\
{[71]}\end{array}$ & & & & & & & \\
\hline
\end{tabular}

CAR, constitutive androstane receptor; PXR, pregnane X receptor; VDR, vitamin D receptor; PPAR, peroxisome proliferator-activated receptor; FXR, farnesoid X receptor; LXR, liver X receptor; ERR, estrogen receptor-related receptor; RAR, retinoic acid receptor; RXR, retinoid X receptor; TR, thyroid hormone receptor; GR, glucocorticoid receptor; MR, mineralocorticoid receptor; PFAS, per- and polyfluoroalkyl substances; PCB, polychlorinated biphenyls; THM, traditional herbal medicines; $\uparrow=$ activation/agonism, $\downarrow=$ inactivation/antagonism; $\mathrm{h}=$ human (in vitro), $\mathrm{r}=$ rodent (in vitro, in vivo). 


\section{Key Characteristics of CAR and Its Activation Process}

The constitutive androstane receptor (CAR, NR1I3) is a member of nuclear receptor subfamily 1I, together with its sisters vitamin D receptor (VDR, NR1I1) and pregnane $X$ receptor (PXR, NR1I2), and a subject of intense research for the past 20 years. The many earlier review articles on CAR properties, target genes, evolution, and other aspects have been listed previously [72] and later progress in the field is also well-documented (e.g., [73-78]). Therefore, we provide below only an overview on key characteristics of CAR.

CAR was initially identified as a constitutively active modulator of retinoic acid receptor signaling [79]. Subsequent discoveries established CAR as a liver-predominant, ligand-activated regulator of xenobiotic-metabolizing enzymes such as cytochrome P450s (CYPs), conjugating enzymes and transporters, and identified the main molecular mechanisms underlying this induction pathway. First, CAR activates the Cyp2b10 gene transcription after exposure of liver cells to phenobarbital (PB) and other PB-like inducing drugs by binding as a heterodimer with retinoid $X$ receptor (RXR) to a distal enhancer sequence termed PBREM [80,81]. During this activation, CAR is translocated from cytoplasm into the nucleus [82] after dissociation of CAR-interacting cytoplasmic partners such as heat shock protein and CCRP [83]. The translocation in turn involves inducer-dependent dephosphorylation of the receptor, which is mediated by protein phosphatase $2 \mathrm{~A}$ that counteracts the action of protein kinase ERK1/2 [84,85].

Consistently with these molecular studies, CAR null mice do not display induction of drug metabolism, proliferation of endoplasmic reticulum, or liver growth in response to $\mathrm{PB}$ or many other rodent tumor promoters $[86,87]$. Differences in CAR protein sequences cause significantly distinct ligand profiles between species [72,88]. In addition, humans but not rodents have splicing isoforms that are differentially activated by ligands [89]. The robust hypertrophy of rodent liver to PB exposure seems to be missing in humans, perhaps due to differences in CAR target genes in these species [90].

Development of various in vitro assays, coupled with mutagenesis and structural models, have clearly established that diverse chemicals act either as direct agonists or inverse agonists of CAR [91-94]. However, some compounds including PB are called indirect activators due to their inability to elicit binding to CAR, as measured by e.g., recruitment of NR coactivators, despite the fact that these compounds can induce CAR target genes [95]. It should be also noted that many CAR-activating chemicals can bind to other NRs, especially to PXR and PPARs [96,97], and several NRs and CAR may crosstalk, notably via sharing of DNA binding sites by CAR and PXR [72], PPAR $\alpha$ [98], and hepatocyte nuclear factor-4 (HNF4; [99]).

CAR-mediated induction is, at least for $\mathrm{PB}$, associated by the attenuation of epidermal growth factor (EGF) signaling [84,100]. Additionally, insulin and CAR pathways have been reported to intersect [101]. Finally, there is evidence that other NRs [72], genetic background [102], fasting [103], and aberration of the circadian clock [104] may enhance CAR expression levels. These interactions provide additional mechanisms to integrate glucose metabolism, energy utilization, liver proliferation, and xenobiotic metabolism.

\section{Metabolic Effects Modulated by CAR}

The many CAR-responsive genes code for proteins involved in disposition of drugs and xenobiotics, cell cycle control, and in endogenous metabolic processes [75,105]. Evidence from in vivo animal and in vitro human studies indicates that CAR is actively controlling key energy metabolism processes, such as hepatic glucose and lipid metabolism and is involved in the pathogenesis of metabolic disorders $[72,73,106]$ (Figure 1). CAR has been reported as a key mediator in protecting against steatosis via suppressing lipogenesis and gluconeogenesis, and further, activation of CAR protects against fatty liver [106]. CAR has also been shown to participate in thyroid hormone metabolism [107-109]. 


\section{CAR activation}

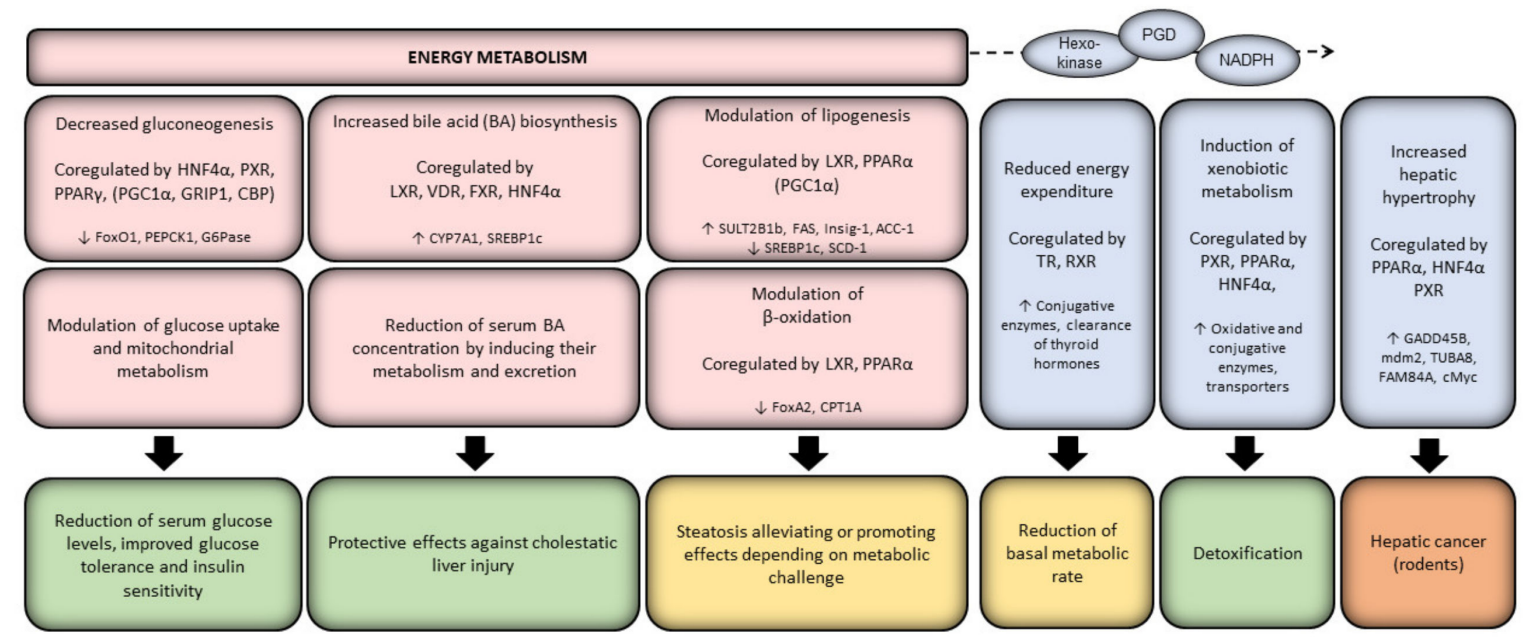

Figure 1. Schematic overview of key regulatory processes affected by CAR. CAR activation modulates key metabolic processes, such as glucose and lipid metabolism and bile acid synthesis via several mechanisms and pathways (as detailed in the main text). These effects depend in part on sex, nutritional status, or metabolic challenge used in animal studies. CAR-mediated induction of genes involved in glucose uptake and utilization (e.g., hexokinase, PGD) generates NADPH, which in turn supports xenobiotic metabolism. Through regulation of thyroid hormone levels, CAR can contribute to energy expenditure and weight loss. CAR alters the expression of genes associated with cell proliferation and oncogenic signaling in rodents. Positive outcomes are depicted with green, ambivalent outcomes with yellow, and adverse outcomes with orange color.

The effects of CAR on metabolic homeostasis are mediated e.g., by reduced expression of several factors associated with energy expenditure, fatty acid synthesis, $\beta$-oxidation, bile acid synthesis, and gluconeogenesis [110,111] (Figure 1). CAR has been connected to metabolic stress during long-term fasting in mice by downregulation of triiodothyronine (T3) and tetraiodothyronine (T4) through the induction of Sult1a1, Sult2a1, and Ugt1a1 genes, thus reducing the basal metabolic rate [112]. Additionally, CAR is required for the PB-induced decrease in T3 and T4 levels [113]. CAR further competes with the thyroid hormone receptor (TR) for binding to the mutual heterodimerization partner retinoid X receptor (RXR) $\alpha$ and NR coregulators [98] and may thus reduce the effects of thyroid hormones by decreasing the ability of TR to regulate its target gene expression.

Activation of CAR has been shown to repress gluconeogenesis $[114,115]$ and to reduce serum glucose levels [115] in mice, and to lower lactate production and glucose consumption [116,117] in HepaRG cells. After a meal, insulin prevents hepatic glucose output by repressing phosphoenolpyruvate carboxykinase-1 (PEPCK1) and glucose 6-phosphatase (G6Pase) transcription. Upon fasting, G6Pase and PEPCK1 genes are reactivated by the transcription factor forkhead box O1 (FoxO1) to initiate gluconeogenesis in the absence of insulin. Mechanistically, CAR can bind and repress FoxO1 [118], preventing it from interacting with the insulin response elements in insulin-like growth factor-binding protein (IGF-BP) 1, pyruvate carboxylase (PCX), fructose bisphosphatase 1 (FBP1), PEPCK1 and G6Pase upstream regions, and thus, suppressing the expression of these gluconeogenic genes [119]. CAR can compete with HNF4 $\alpha$ for binding to the PEPCK promoter [99] or for metabolic coregulators, such as peroxisome proliferator-activated receptor $\gamma$ coactivator-1 (PGC1) $\alpha$ or glucocorticoid receptor-interacting protein 1 (GRIP1) [110,120]. Further, CAR can suppress hepatic gluconeogenic gene expression through posttranslational regulation of degradation and subcellular localization of PGC1 $\alpha$, representing a possible cellular adaptive mechanism in energy-restricted conditions [121]. 
Activation of CAR by TCPOBOP has been shown to decrease glucose transporter (GLUT) 2 expression in wild-type but not in CAR null mice [110], indicating a reduction of hepatic glucose uptake, which may lead to inhibition of glycogenesis and stimulation of glycogenolysis.

CAR activation also enhances mitochondrial metabolism and increases bile acid production, lactate elimination, and glucose production [116,117,122], resulting in improved glucose tolerance and insulin sensitivity $[115,121]$. Agonist-activated CAR has been shown to improve insulin sensitivity in high fat diet (HFD)-fed and genetically obese $o b / o b$ mice, while CAR null and antagonist-treated mice are resistant to insulin $[57,123]$. In early human studies, PB appeared to lower fasting plasma glucose and insulin levels, improve glucose tolerance and insulin response to glucose loading without affecting the body weight in diabetic patients [124,125]. Similar effects are seen in mice, where TCPOBOP-activated CAR prevents or ameliorates obesity and improves T2D symptoms induced by HFD in wild-type mice $[115,126]$. PB has later been shown to act as an insulin receptor antagonist and to elicit both CAR-independent increases and CAR-dependent decreases of blood glucose levels in wild-type and CAR null mice [101]. Long-term CAR activation in mice increases glucose uptake and utilization in the liver [115], by upregulating glucose transporters, glycolytic and mitochondrial pyruvate-metabolizing genes, and glycolytic intermediates in the liver [127]. Fasting and caloric restriction increases the activity of certain metabolic pathways, which may be regulated by CAR without exposure to exogenous agonists or activators $[103,128]$. The fasting-induced expression and activation of CAR has been shown to be controlled by the interplay of at least PPAR $\alpha$, HNF $4 \alpha$ and PGC1 $\alpha[129,130]$, implying a feedback regulation of glucose levels. Recently, the growth arrest and DNA damage-inducible gene $45 \mathrm{~b}$ (Gadd45b), associated with liver growth (Figure 1), is required for anti-diabetic and obesity effects of CAR in vivo [131] but deciphering the exact molecular mechanisms requires further studies.

The effects of CAR to lipid metabolism are more controversial. Overall, several studies have shown that modulation of CAR may lead to changes hepatic triglyceride levels and thus, constitutes an important adverse outcome pathway (AOP) in metabolic effects of xenobiotic compounds $[129,132]$. In rodents, several studies have reported CAR as a key mediator in protecting against steatosis via suppressing lipogenesis and gluconeogenesis and further, activation of CAR protects against fatty liver [133]. Activation of CAR has been shown to alleviate hepatic steatosis and fatty liver by inhibiting hepatic lipogenesis and inducing $\beta$-oxidation in HFD-fed and TCPOBOP-treated mice $[115,126]$. Treatment of hyperlipidemic mice with CAR agonists decreases hepatic content of cholesterol by enhancing its metabolism to bile acids [134]. Activation of CAR reduces serum bile acid concentrations through induction of expression of genes, such as CYPs, UGTs, and SULTs, involved in bile acid metabolism and excretion $[135,136]$. In mice, CAR is involved in the regulation of enzymes producing bile acids [137] and its activation protects against cholestatic livery injury. Conversely, CAR activation contributes to increased lipogenesis, increased circulating fatty acid and ketone bodies, and represses $\beta$-oxidation $[111,114,115,133]$. Further, in primary hepatocytes, CAR activation did not affect the expression of lipogenic genes [138]. This discrepancy may be in part due to differences in the metabolic challenge and regulation of multiple pathways in diverse experimental settings. It should be noted that e.g., HFD feeding influences the expression/activation of NRs and their target genes [139]. Mechanistically, CAR has been shown to affect the insulin-induced gene-1 (INSIG1) and suppress lipogenic gene expression $[115,129,140]$. Further, activation of CAR in wild-type mice, but not in CAR/PXR null animals, leads to downregulation of PPAR $\alpha$ and its target genes, such as carnitine palmitoyltransferase-1 (CPT1) that is involved in fatty acid oxidation [141]. This may be caused by CAR-dependent repression of FoxA2 and HNF $4 \alpha$ transcription factors. CAR modulates the expression of fatty acid synthase (FASN), acetyl-CoA carboxylase 1 (ACC1), and stearoyl-CoA desaturase 1 (SCD1) that control de novo fatty acid biosynthesis [119]. While the expression of FASN and ACC1 increased after CAR activation in wild-type mice, the expression of SCD1 and the sterol regulatory element-binding protein-1c (SREBP-1c) was significantly decreased, suggesting complexities in regulatory networks. Interestingly, SREBP-1 seems to prevent interaction of coregulators with CAR, thereby inhibiting transcriptional activity of CAR and the expression of its target genes [142]. 
According to recent studies, at least some of the CAR-mediated metabolic effects are sex-dependent [143-145]. While CAR null male mice develop a range of metabolic disorders (obesity, insulin insensitivity, glucose intolerance, dyslipidemia, and liver steatosis), these symptoms were either mild or not observed in CAR null females [143]. However, female CAR null mice developed more severe symptoms after ovariectomy. Similar dimorphic effects have been observed in rats, with males manifesting with increased liver weight, reduced serum T4, and decreased serum total cholesterol, while females were unaffected [145]. Maternal CAR activation has been shown to improve glucose tolerance and to ameliorate gestational hyperglycemia and increase fetal weight in HFD-fed mice [146].

Even though the role of CAR in regulation of energy homeostasis and adverse metabolic effects has been established in rodents, many issues are still unclear. In contrast to classical hormone receptors, wide species differences in the ability of chemicals to modulate CAR activity cause significant challenges in predicting or understanding the metabolic consequences of CAR modulation by EDCs in humans $[138,147,148]$. As an example, CAR activation in mouse primary hepatocytes repressed the expression of genes involved in gluconeogenesis, lipogenesis, and fatty acid synthesis, activation of CAR in human primary hepatocytes inhibited gluconeogenesis without suppressing fatty acid synthesis.

Considerable crosstalk between CAR and other NRs and transcription factors that regulate lipid metabolism (PXR, FXR, PPARs, and LXR) [114] and glucose metabolism (PXR, HNF4, CREB, and FOX proteins) [149] lead to complex regulatory networks. Additionally, the metabolic enzymes and transporters activated by CAR are involved in clearance of metabolically relevant endogenous substances that include ligands of other NRs (bile acids, bilirubin, vitamin D, and thyroid hormones) (e.g., $[113,114,150,151])$. The lack of human CAR-selective tools adds to the challenge of deciphering the detailed role of CAR in metabolic processes. The 6-(4-chlorophenyl)imidazo[2,1-b][1,3]thiazole5-carbaldehyde-O-(3,4-di-chlorobenzyl)oxime (CITCO) is routinely used as a positive control substance selective to human CAR. Recently, it was shown to bind and activate human PXR in hepatic cell models [152]. Further, as humans are continuously exposed to a large variety of EDCs, which may act in additive or synergistic ways, deciphering the net effects and connecting a specific EDC to specific regulator and metabolic alteration is a challenging task.

\section{Metabolic Effects of EDC Classes Potentially Mediated by CAR}

Below, we present evidence of main EDC classes as CAR activators and their potential metabolic effects (Table 2). It should be noted that a direct role of CAR in metabolic disruption, especially for humans, cannot be easily determined due to lack of highly selective CAR agonists, promiscuity of many EDCs for many NRs and other targets (Table 1), the complex interplay between NRs in controlling the hepatic metabolism, and species differences among animal species and with humans. 
Table 2. Examples of CAR related chemicals and their proposed metabolic effects via CAR.

\begin{tabular}{|c|c|c|c|c|c|}
\hline Chemical Group & $\begin{array}{l}\text { Example Compound } \\
\text { (CAS) }\end{array}$ & $\begin{array}{l}\text { Reported } \\
\text { CAR } \\
\text { Response }\end{array}$ & $\begin{array}{l}\text { Toxcast } \\
\text { AC50 }(\mu \mathrm{M})\end{array}$ & Metabolic Effect with Probable CAR Participation & References \\
\hline \multirow{2}{*}{ Bisphenols } & $\begin{array}{l}\text { Bisphenol A, BPA } \\
\quad(80-05-7)\end{array}$ & Agonist & $\begin{array}{c}46.4^{\mathrm{RG},(\mathrm{a})} \\
20.3^{\mathrm{RG},(\mathrm{b})} \\
0.00892^{\mathrm{BA},(\mathrm{c})}\end{array}$ & $\begin{array}{c}\text { Human: childhood and adulthood obesity } \uparrow \text {, diabetes } \uparrow \\
\text { Mouse: glucose tolerance } \downarrow\end{array}$ & {$[4,153,154]$} \\
\hline & $\begin{array}{l}\text { Tetrabromobis-phenol A, } \\
\text { TBBPA } \\
\text { (79-94-7) }\end{array}$ & Antagonist & $29.3^{R G,(b)}$ & $\begin{array}{l}\text { Rat: thyroid hormone level } \downarrow \text {, reactive oxygen species } \uparrow \text {, } \\
\text { bodyweight } \uparrow \text { at high dose levels }\end{array}$ & [155] \\
\hline \multirow[b]{2}{*}{ Phthalates } & $\begin{array}{l}\text { Dibutyl phthalate, DBP } \\
(84-74-2)\end{array}$ & Antagonist & $\begin{array}{l}16.1^{\mathrm{RG},(\mathrm{b})} \\
16.2^{\mathrm{BA},(\mathrm{c})}\end{array}$ & $\begin{array}{c}\text { Human: diabetes } \uparrow \text {, insulin resistance } \uparrow \\
\text { Rat fetus: steroid metabolism } \uparrow\end{array}$ & {$[4,24,156,157]$} \\
\hline & $\begin{array}{l}\text { Di-(2-ethylhexyl)-phthalate, } \\
\text { DEHP } \\
(117-81-7)\end{array}$ & $\begin{array}{c}\text { Agonist } \\
\text { (hCAR2) }\end{array}$ & $\begin{array}{l}\text { inactive } \\
\text { RG, (a), (b), BA, (c), } \\
\text { RG, (d) }\end{array}$ & $\begin{array}{c}\text { Human: birth weight } \downarrow \text { childhood and adult obesity } \uparrow \text {, diabetes } \uparrow \text {, } \\
\text { insulin resistance } \uparrow \text {, glucose tolerance } \downarrow \\
\text { Rat: fatty acid metabolism } \uparrow \text {, tryptophan metabolism } \uparrow\end{array}$ & {$[4,156,158,159]$} \\
\hline \multirow{2}{*}{$\begin{array}{l}\text { Perfluoro-alkylated } \\
\text { substances }\end{array}$} & $\begin{array}{l}\text { Perfluorooctanoic acid, PFOA } \\
\qquad(335-67-1)\end{array}$ & Activator & $18.7^{\mathrm{BA},(\mathrm{c})}$ & $\begin{array}{c}\text { Human: glucose tolerance } \downarrow \text { adult obesity } \uparrow \text {, child adiposity } \uparrow \text {, } \\
\text { diabetes } \uparrow \\
\text { Mouse: hepatic steatosis } \downarrow \\
\text { Rat: mitochondrial respiration } \downarrow \\
\text { Rat hepatocytes: mitochondrial respiration } \downarrow \text {, energy metabolism } \downarrow \text {, } \\
\text { fatty acid oxidation } \uparrow, \text { hepatic triglycerides } \uparrow\end{array}$ & {$[4,28,106,159-162]$} \\
\hline & $\begin{array}{l}\text { Perfluorooctane sulfonate, } \\
\text { PFOS } \\
(1763-23-1)\end{array}$ & Antagonist & $17.6^{\mathrm{BA},(\mathrm{c})}$ & $\begin{array}{c}\text { Human: adult obesity } \uparrow \\
\text { Rat: mitochondrial respiration } \downarrow \text { Rat hepatocytes: mitochondrial } \\
\text { respiration } \downarrow \text {, } \\
\text { energy metabolism } \downarrow \text {, fatty acid oxidation } \uparrow \text {, hepatic triglycerides }\end{array}$ & {$[4,106,159,160,162,163$} \\
\hline \multirow{3}{*}{$\begin{array}{l}\text { Brominated ND } \\
\text { organo-phosphate } \\
\text { flame retardants }\end{array}$} & $\begin{array}{l}\text { Polybrominated diphenyl ether } \\
\qquad 47, \text { BDE- } 47 \\
(5436-43-1)\end{array}$ & $\begin{array}{l}\text { Activator } \\
\text { (mCAR, } \\
\text { hCAR) }\end{array}$ & $39.1^{R G,(a)}$ & $\begin{array}{c}\text { Human: obesity } \uparrow \\
\text { Mouse: thyroid hormone } \downarrow \text {, fasting glucose } \uparrow \text { (males), glucose } \\
\text { clearance } \uparrow \text { (females) }\end{array}$ & {$[31,32,154,164,165]$} \\
\hline & $\begin{array}{l}\text { Triphenyl phosphate, TPP } \\
(115-86-6)\end{array}$ & Agonist & $18.2^{R G,(a)}$ & $\begin{array}{c}\text { Mouse: bodyweight } \downarrow \text {, energy intake } \downarrow \text {, ghrelin } \uparrow \text {, leptin } \downarrow \text {, insulin } \downarrow \text {, } \\
\text { fasting glucose } \uparrow \text { (males) }\end{array}$ & [32] \\
\hline & $\begin{array}{l}\text { Tris(1,3-dichloro-2-propyl) } \\
\text { phosphate, TDCPP } \\
\text { (13674-87-8) }\end{array}$ & Antagonist & $\begin{array}{l}34.7^{\mathrm{RG},(\mathrm{d})} \\
0.586^{\mathrm{RG},(\mathrm{b})} \\
1.78^{\mathrm{RG},(\mathrm{e})}\end{array}$ & $\begin{array}{c}\text { Mouse: bodyweight } \downarrow \text {, energy intake } \downarrow \text {, ghrelin } \uparrow \text {, leptin } \downarrow \text {, insulin } \downarrow \text {, } \\
\text { fasting glucose } \uparrow \text { (males) }\end{array}$ & [32] \\
\hline
\end{tabular}


Table 2. Cont.

\begin{tabular}{|c|c|c|c|c|c|}
\hline Chemical Group & $\begin{array}{l}\text { Example Compound } \\
\text { (CAS) }\end{array}$ & $\begin{array}{l}\text { Reported } \\
\text { CAR } \\
\text { Response }\end{array}$ & $\begin{array}{c}\text { Toxcast } \\
\text { AC50 }(\mu \mathrm{M})\end{array}$ & Metabolic Effect with Probable CAR Participation & References \\
\hline \multirow[t]{2}{*}{ PCBs } & $\begin{array}{c}\text { PCB153 } \\
(35065-27-1)\end{array}$ & Activator & $\begin{array}{l}\text { inactive } \\
\text { RG, (a), (d) }\end{array}$ & $\begin{array}{c}\text { HepG2: EGFR signaling } \downarrow \\
\text { Mouse: blood glucose } \uparrow \text { (males), glucagon } \uparrow \text { (females), } \\
\text { diet-induced obesity } \uparrow \text {, non-alcoholic steatohepatitis } \uparrow \text { (males), } \\
\text { visceral adiposity } \uparrow * \text {, hepatic steatosis } \uparrow *, \beta \text {-oxidation } \downarrow * \text {, lipid } \\
\text { biosynthesis } \uparrow * \text {, glucose tolerance }\end{array}$ & {$[40,100,166,167]$} \\
\hline & $\begin{array}{l}\text { Arochlor } 1260 \\
(11096-82-5)\end{array}$ & Activator & $\begin{array}{l}\text { inactive } \\
\mathrm{RG} \text {, (a), (d) }\end{array}$ & $\begin{array}{c}\text { Mouse: EGFR signaling } \downarrow \text {, energy metabolism } \downarrow \text {, metabolic } \\
\text { syndrome } \uparrow, \text { insulin sensitivity } \uparrow *\end{array}$ & {$[168,169]$} \\
\hline $\begin{array}{l}\text { Pesticides, } \\
\text { insecticides }\end{array}$ & $\begin{array}{l}\text { Dichlorodiphenyltrichloroethane, } \\
\text { o, p'-DDT } \\
\text { (789-02-6) }\end{array}$ & Agonist & $4.05^{R G,(a)}$ & $\begin{array}{c}\text { Human: childhood obesity } \uparrow \text { (prenatal exposure), adult diabetes } \uparrow \\
\text { (prenatal exposure), Mouse: glucose tolerance } \downarrow \text { (perinatal and } \\
\text { adult exposure), insulin secretion } \downarrow\end{array}$ & {$[4,153]$} \\
\hline \multirow[b]{2}{*}{ Fungicides } & Cyproconazole (94361-06-5) & Agonist & $30.2^{\mathrm{BA},(\mathrm{c})}$ & $\begin{array}{c}\text { Mouse: lipid accumulation } \uparrow \text {, altered fatty acid and phospholipid } \\
\text { metabolism, }\end{array}$ & [170-173] \\
\hline & Propiconazole (60207-90-1) & Agonist & $\begin{array}{l}48.2^{\mathrm{RG}, \mathrm{a})} \\
16.4^{\mathrm{BA},(\mathrm{c})} \\
65.8^{\mathrm{RG},(\mathrm{b})}\end{array}$ & $\begin{array}{c}\text { Mouse: liver weight } \uparrow \text {, fatty acid synthesis } \uparrow \text {, hepatic triglyceride } \\
\text { accumulation } \uparrow \text {, steatosis } \uparrow \text {, phospholipid degradation } \uparrow \text {, } \\
\text { tryptophan metabolism } \uparrow \\
\text { Rat: fatty acid synthesis } \uparrow, \text { hepatic triglyceride accumulation } \uparrow \text {, } \\
\text { steatosis } \uparrow\end{array}$ & {$[55,57,174,175]$} \\
\hline Triclosan & $\begin{array}{l}\text { Triclosan } \\
(3380-34-5)\end{array}$ & $\begin{array}{c}\text { Agonist } \\
\text { (hCAR3) } \\
\text { Inverse agonist } \\
\text { (hCAR, mCAR, } \\
\text { rCAR) }\end{array}$ & $\begin{array}{l}4.71^{R G,(b)} \\
85 \mathrm{RG},(\mathrm{d})\end{array}$ & $\begin{array}{c}\text { Human: birth weight } \downarrow \\
\text { Mice: body weight } \downarrow \text { (during exposure) } \\
\text { Rat: hepatic catabolism of thyroid hormones } \uparrow \text {, thyroid hormone } \downarrow\end{array}$ & {$[4,62,176]$} \\
\hline $\begin{array}{l}\text { Natural } \\
\text { compounds, } \\
\text { phyto/myco- } \\
\text { estrogens }\end{array}$ & $\begin{array}{l}5,7-\mathrm{OH} \text { flavone, chrysin } \\
\quad(480-40-0)\end{array}$ & $\begin{array}{l}\text { Agonist } \\
\text { (mCAR) } \\
\text { Activator } \\
\text { (hCAR) }\end{array}$ & 39.1 RG, (a) & $\begin{array}{l}\text { Mice: detoxification } \uparrow \text {, energy metabolism } \uparrow \text {, fatty acid } \\
\text { accumulation } \downarrow \text { in mouse livers with alcohol-induced stress. } \\
\text { A431 cells: inhibit EGFR autophosphorylation at Tyr1068 }\end{array}$ & {$[177,178]$} \\
\hline $\begin{array}{l}\text { Alkylphenols and } \\
\text { derivatives }\end{array}$ & $\begin{array}{l}\text { Nonylphenol } \\
(104-40-5)\end{array}$ & Agonist & $68.7^{R G,(a)}$ & $\begin{array}{c}\text { Daphnia magna: testosterone elimination } \downarrow \text {, } \\
\text { reduced/dehydrogenated testosterone metabolites } \uparrow \text {, androgen } \\
\text { accumulation } \uparrow\end{array}$ & {$[13,14,179]$} \\
\hline Parabens & $\begin{array}{l}\text { Butylparaben } \\
\quad(94-26-8)\end{array}$ & Agonist & $\begin{array}{l}36.5^{R G,(a)} \\
60.2^{R G,(b)}\end{array}$ & $\begin{array}{c}\text { Human: adverse cardiometabolic effects, blood glucose } \uparrow \\
\text { (pregnant women), diabetes } \uparrow \text {, obesity } \uparrow\end{array}$ & [180] \\
\hline
\end{tabular}




\subsection{Bisphenols}

These precursors to polycarbonate and vinyl ester plastics are of concern due to high affinity of some bisphenols to estrogen receptors [181] and their association with childhood and adult obesity $[4,154]$ (Table 2). In vitro studies have suggested that exposure to bisphenol A (BPA) can cause metabolic dysfunction in adipocytes [182], while early exposure has been shown to cause weight increase particularly in female rats [183]. In epidemiological studies, BPA has been shown to affect insulin synthesis and release as well as insulin signaling [184]. In vitro NR binding assays indicated a very high affinity $(<20 \mathrm{nM})$ of several bisphenols such as bisphenol A, AF, B, and C for human CAR [185], which was similar to their affinity for estrogen receptors (Table 2.). In contrast, human PXR bound these bisphenols only at micromolar concentrations. In agreement with this study, bisphenols A, B, and AF were among the most effective CAR activators in the yeast two-hybrid assay [186], and bisphenol A was a strong activator of human CAR1 and CAR3 isoforms while human CAR2 and PXR were refractory [11]. In addition, tetrabromobisphenol $\mathrm{A}$ is a flame retardant that appears to weakly activate CAR and reduce thyroid hormone levels in subacute toxicity studies rats [155], although similar dosages in other studies have not resulted in CYP2B induction [187] (Table 2). The higher propensity of CAR activation as compared to other hepatic NRs suggest a connection with the metabolic disorders associated with bisphenols.

\subsection{Phthalates}

They are a widely used group of plasticizers present in containers, coatings, tubes, and in myriad of other household appliances. Di(2-ethylhexyl)-, diisononyl-, and dibutyl-phthalates (DEHP, DINP, DBP) are among the most commonly used, and as esters, phthalates are easily hydrolyzed to their monoester derivatives MEHP, MINP, and MBP. Epidemiological studies have associated exposure to phthalates not only to maturation but also to increased risk of childhood obesity, diabetes, and impaired glucose tolerance [4,157] (Table 2). Mechanistically, the adverse effects on lipid metabolism and obesity could be caused by activation of PPAR isoforms in several tissues [188,189]. However, di- and monoester phthalates activate human and mouse CAR and PXR in reporter gene assays [11,23-25] (Table 2). Rodent models $[156,158,190]$ also show evidence of CAR- and PXR-dependent activation. In addition, activation of CAR seems to downregulate and suppress PPAR-mediated signaling $[141,191]$ (Table 2). These findings may contribute to phthalate-associated disturbances in glucose homeostasis.

\subsection{Perfluoroalkylated Substances (PFAS)}

These compounds, typified by perfluorooctanoic acid (PFOA) and perfluorooctane sulfonate (PFOS), have numerous uses in consumer and industrial products as e.g., surfactants and water-repelling coatings. They accumulate in organisms due to their very slow metabolism, raising therefore concerns about toxicity [192]. More recently, a strong association with childhood adiposity, adult obesity and impaired glucose tolerance in human cohort studies was reported [4]. The risk of thyroid disruption is estimated low [193] and linkage between sex hormone-dependent effects weak or non-consistent (e.g., [194,195]).

Early rodent studies found that PFOA and PFOS exposure leads to activation of PPAR $\alpha$-controlled target genes but also to a strong induction of CYP2B and CYP3A mRNAs in a CAR-dependent fashion [162,163], similarly to some phthalates (Table 2). Shorter-chain fluorinated carboxylic and sulfonic acids $[57,145]$ also induced CAR target genes although negative findings have also been published [196]. The mode of CAR activation is not clear as some reports suggest either a direct [197] or an indirect mechanism [28], or no effect in reporter assays [198]. It is of interest that CAR and PPAR signaling pathways are mutually suppressive $[105,199]$.

One of possible metabolic effects mediated by PFOA/PFOS-activated CAR is the decrease in serum glucose [163] (Table 2). The increases in fatty acid oxidation is more likely governed by PPAR $\alpha$ while accumulation of triglycerides $[160,200]$ could in part be due to inhibition of PPAR $\alpha$ signaling 
by activated CAR [75]. However, PFOA seems to decrease the severity of preexisting fatty liver disease [161], a process that is modulated by CAR. More research in PFOA/PFOS-mediated metabolic effects and involvement of CAR, especially in human systems, are needed.

\subsection{Flame Retardants}

Flame retardants are widely used in textiles, furniture, electronics, and other plastic-based industrial or consumer products. The main classes are brominated diphenyl ethers (BDEs) and organophosphates, both of which are of concern for their endocrine-disruptive effects $[4,201]$. With respect to potential CAR-mediated effects, both BDE-47 and BDE-209 are mouse and human CAR activators, and they increase serum glucose levels [31-33] and T4 clearance [164] in animal models (Table 2). For organophosphates, human CAR is prone to activation of triphenyl, tricresyl, and isopropylated phenyl phosphates [202] (Table 2). Human PXR is also modestly activated while the responses of mouse CAR and PXR are weaker. A mixture of tris(1,3-dichloro-2-propyl)phosphate, triphenyl phosphate, and tricresyl phosphate activated CAR in the mouse model, concomitant with changes in leptin and insulin levels and energy intake [32]. The species differences in CAR activation potential of various BDE and organophosphate congeners [31,202,203], overlap with PXR activation, and scarce information on congener-specific metabolic effects complicate the interpretation of these studies.

\subsection{Polychlorinated Biphenyls (PCBs)}

This group of persistent organic pollutants has been associated with type 2 diabetes and obesity [204,205]. Earlier studies have showed that both human and rodent CAR and PXR are activated by non-planar PCBs $[40,41,203]$ with a tendency of human CAR being activated efficiently and with a preference of CAR over PXR (Table 2). No clear structure-activity relationship with respect to CAR activation among PCB congeners has been identified $[41,206]$. Both planar (dioxin-like) and non-planar PCBs have been reported to attenuate EGF signaling in analogy to PB $[100,168]$. However, the lack of CYP2B induction by planar PCBs implies some divergence in signal transduction at the EGF receptor level. Finally, several PCBs seem to increase expression of CAR in a human hepatic cell line [207], suggesting that CAR expression is controlled by both exogenous and endogenous signaling [72] which raises the possibility of synergistic PCB action by both activation and induction of CAR.

With regard to metabolic effects, PCB153 is a CAR-activating compound that augments the hepatic steatosis and inflammation observed in HFD-fed mice [167] (Table 2.). Increases in blood glucose levels in male mice have also been noted [166] although PCB153-elicited induction seems stronger in females [57]. In a cross-generational study, F1 mice exposed to PCB153 in utero and during lactation showed decreased serum lipid levels and better glucose tolerance during a HFD challenge [208]. In addition, exposure to the PCB mixture (Aroclor 1260) has been associated with obesity and fatty liver disease (Table 2.). This PCB mixture seems to affect several metabolism-linked NRs by activating PXR and CAR isoforms, antagonizing PPAR $\alpha$ [209], and influencing aspects of energy metabolism, including lipid oxidation, food intake, insulin sensitivity, and gluconeogenic gene expression in CARor PXR-dependent fashion in mice [169].

\subsection{Pesticides}

Several groups of pesticides have been linked to deleterious effects on neuroendocrine, reproductive, and immunological functions and dysregulation of energy metabolism [3]. The use of organochlorinated compounds such as dieldrin or endosulfan have largely been abandoned but both activate CAR and PXR in vitro, and increase expression of their CYP target genes in animals or in human HepaRG cells $[45,46,210,211]$. The now banned but environmentally persistent DDT, methoxychlor and their metabolites are also direct activators of both rodent and human CAR and PXR [186,210,212,213]. 
More recently, numerous pesticides have been screened for NR activation. Activation of human CAR and induction of CYP2B6 mRNA in HepaRG cells seems more pronounced than that of mouse CAR by many pesticides of the organophosphate, pyrethroid, and carbamate classes [44] (Table 2). Most pyrethroids tested activate mouse, human, and rat PXR in vitro, and activation was decreased by microsomal metabolism of these compounds [47,214]. A large number of organophosphates are also PXR activators albeit often in a species-dependent manner [214]. A prototypical triazine compound, atrazine, strongly induced CYP2B6 expression without any apparent human CAR activation [44] or EGF receptor binding [100], a finding that may be explained by increased expression of CAR [215] and contribution to CYP2B6 induction by atrazine-activated PXR.

Despite the strong evidence for CAR and/or PXR activation in cellular systems, these compound classes have mostly been investigated in animal studies for their hepatotoxic or tumor-promoting properties related to CAR (e.g., [87]) without a major focus on metabolic changes. Notably, recent reviews on endocrine disruptor-related metabolic processes $[4,153,216]$ only mention the most persistent organochlorine compounds but not the more labile organophosphate pesticides.

There is limited concern on the reproductive adverse effects of azole fungicides in animal studies (e.g., $[217,218]$ ) while they often cause hepatocyte hypertrophy, liver toxicity, and even neoplasm formation in rodents (e.g., $[219,220])$. The activation of rodent and human AhR, CAR, and PXR by 20 different azole fungicides has recently been reviewed in detail [55] and we provide here only some examples (Table 2). Reporter gene assays and mRNA induction studies show that propiconazole is a moderate activator of human and rodent CAR. This is supported by mouse and rat studies in vivo [56,174]. At the same time, propiconazole activates PXR in all three species [55]. In contrast, tebuconazole appears to antagonize human CAR [56] while activating the rodent receptors. Coincidentally, tebuconazole-induced liver hypertrophy is not as highly dependent on CAR as with cyproconazole or fluconazole [172]. Vinclozolin is an anti-androgenic fungicide [221] that has been tested in Toxcast high-throughput analyses for NR activation; however, it does not show consistent activation of CAR or PXR [222]. A common metabolic outcome by azole fungicides in rodents is the frequent steatosis which is caused by activation of fatty acid synthesis, mostly via PXR and less frequently by CAR-mediated action $[55,223]$

\subsection{Triclosan}

Triclosan is an antimicrobial chlorinated phenoxyphenol used until recently in multiple personal care products, detergents, and technical equipment. Despite its weak affinity for steroid hormone receptors, there is little evidence for its adverse reproductive effects [224,225]. The response of CAR to triclosan seems highly species-specific: mouse CAR and human CAR3, a splice isoform with low basal activity, are activated by triclosan, while it is an inverse agonist for rat CAR and the main human isoform CAR1 [62,176,226] (Table 2). In a similar fashion, triclosan activated human PXR but not rat PXR [62], and mouse PPAR $\alpha$ but not human PPAR $\alpha$ [63]. These complex patterns may explain in part the inconsistent link between childhood obesity and triclosan exposure [225]. However, triclosan-induced decreases in T4 levels in the rat may be understood by CAR/PXR-mediated induction of T4-metabolzing enzymes [112,227].

\subsection{Other CAR-Modulating EDC Classes with Limited Evidence for Metabolic Disruption}

Alkylphenols are widely used as additives to lubricants and as precursors in chemical synthesis of e.g., polymers, surfactants, and detergents, such as alkylphenol ethoxylates which are degraded back to relatively persistent alkylphenols in the environment. Due to their mimicry of estrogenic substances, alkylphenols are thought to disrupt endocrine functions [228] (Table 2). Studies on their ability to modulate CAR are quite sparse. Nonylphenol activated mouse CAR in reporter gene assays and in mouse model albeit only in the females [13] which may be explained by the female-predominant expression of CAR and responsiveness of its target genes $[229,230]$. Surprisingly, nonylphenol did not activate CYP expression in PXR null mice where CAR is present, suggesting interplay between 
the two NRs [14]. Nonylphenol appeared to induce CYP2B genes in human primary hepatocytes and in humanized CAR mice [231] and later studies using the yeast two-hybrid assay demonstrated that many linear or branched chain alkylphenols, including nonylphenol, can activate human CAR at low to sub-micromolar concentrations [186]. Studies on alkylphenol-induced and CAR-mediated changes in metabolic processes have not been performed yet.

Parabens are $p$-hydroxybenzoic acid esters used as antibacterial preservatives in many types of consumer products. Although widespread, they are regarded as non-persistent due to their relatively rapid hydrolysis [232]. There is limited evidence for their endocrine effects although metabolic [180] (Table 2), and reproductive [233] outcomes have been reported. A recent study [60] tested 17 different parabens in NR activation assays at low micromolar concentrations. They found that rat CAR was weakly activated (2-fold) by butyl- and isobutylparabens, inverse agonism was seen with longer pentyl- and hexylparabens, and butylparaben-mediated activation was abrogated upon metabolism. Rat PXR, human PXR, and rat PPAR $\alpha$ were also modestly responsive to various paraben derivatives. Unfortunately, mouse and human CAR were not tested. Human CAR was activated weakly by linear parabens in a yeast two-hybrid assay [186]. The high concentrations used, the narrow range of activating ligands, and their metabolic lability suggest that parabens are not likely potent CAR-dependent metabolic modulators, although definitive studies are lacking at the moment.

\subsection{Other CAR-Modulating Compounds}

A large repertoire of pharmaceuticals are CAR activators [72,94], while information on their effects on energy metabolism is largely unknown, and not further analyzed in this work. As one example, exposure to statins is a known risk factor for type 2 diabetes (e.g., [234]). Although statins can activate CAR modestly [235], they affect PXR more strongly [236]. Other mechanisms underlying the statin-elicited increase in blood glucose levels likely exist [237]. Similarly, traditional herbal medicines are often CAR/PXR activators [238] and there is some evidence for their efficacy in alleviation of some aspects in liver diseases $[239,240]$. Many flavonoids and natural estrogenic compounds are either direct or indirect CAR activators $[177,241,242]$. Some of them have been reported to improve glucose balance in diabetic mice [243] or reduce fatty acid accumulation in a CAR-dependent fashion [178], although downregulation of CAR target genes has also been noted [244]. Aryl hydrocarbon receptor (AhR) mediates the main effects of 2,3,7,8-tetrachlorodibenzo-p-dioxin (TCDD) and other dioxin-like compounds (e.g., [245]) which can impair glucose metabolism [246,247] and cause fat accumulation [248]. In addition, AhR activation may also lead to upregulation of CAR expression [249], perhaps as a secondary counteracting effect of the metabolic disruption. It is unclear if this is a direct transcriptional effect or due to AhR-mediated disruption of circadian regulation [250].

\section{Future Directions}

Metabolic processes in the liver are highly interconnected and subject to regulation by diverse signals that include e.g., neuronal control of food intake and satiety, circadian rhythms, production, use, and storage of glucose and lipids in the liver and inputs from other tissues such as intestine and muscle $[5,6]$. Nuclear receptors are only one part of this complex network. As evident from the previous sections, suspected metabolism-disrupting compounds are seldom specific for any one NR: for example, CAR activators are often ligands for PXR and PPAR $\alpha$, which also coregulate overlapping target genes [7]. There is a lack of sufficiently selective tool compounds that are both non-toxic and have favorable pharmacokinetics for teasing out CAR-dependent functions in normal human hepatocytes $[8,152]$. The interpretation of animals studies are fraught with complications due to large species differences between CAR and PXR ligand profiles and their target genes-this may not be easily alleviated even by the use of humanized mice [90] without careful and wide-ranging analysis of affected target genes. Further development of long-term human hepatocyte cultures, in connection of modern gene knockdown techniques, is likely to provide better and disease-relevant models for utilization in studies of CAR and PXR [251,252]. The effects of metabolic disruptors are affected not only 
by genetic and epigenetic variation among NRs and their target genes [253], but also by the type of diet that potentially predisposes or protects individuals from adverse effects $[169,254]$. Finally, studies on human-relevant mixtures of metabolic disruptors is largely missing [7].

Author Contributions: P.H. conceived the paper and supervised its writing. J.K., J.N. and P.H. wrote the draft, reviewed, and edited it. All authors have read and agreed to the final version of the manuscript.

Funding: The project EDCMET has received funding from the European Union's Horizon2020 research and innovation programme under grant agreement No 825762. P.H. is the recipient of Nannerl O. Keohane Distinguished Visiting Professorship at the University of North Carolina at Chapel Hill and Duke University.

Conflicts of Interest: The authors declare no conflict of interest. The funders had no role in the design of the study; in the collection, analyses, or interpretation of data; in the writing of the manuscript, or in the decision to publish. The information in this manuscript reflects only the authors' views and the European Commission is not responsible for any use that may be made of the information it contains.

\section{References}

1. Gore, A.C.; Chappell, V.A.; Fenton, S.E.; Flaws, J.A.; Nadal, A.; Prins, G.S.; Toppari, J.; Zoeller, R.T. EDC-2: The Endocrine Society's Second Scientific Statement on Endocrine-Disrupting Chemicals. Endocr. Rev. 2015, 36, E1-E150. [CrossRef] [PubMed]

2. Bergman, Å.; Heindel, J.J.; Jobling, S.; Kidd, K.A.; Zoeller, R.T. State of the Science of Endocrine Disrupting Chemicals -2012; An assessment of the state of the science of endocrine disruptors prepared by a group of experts for the United Nations Environment Programme and World Health Organization; WHO: Geneva, Switzerland; UNEP: Nairobi, Kenya, 2013; pp. 1-296.

3. Yilmaz, B.; Terekeci, H.; Sandal, S.; Kelestimur, F. Endocrine disrupting chemicals: Exposure, effects on human health, mechanism of action, models for testing and strategies for prevention. Rev. Endocr. Metab. Disord. 2020, 21, 127-147. [CrossRef] [PubMed]

4. Kahn, L.G.; Philippat, C.; Nakayama, S.F.; Slama, R.; Trasande, L. Endocrine-disrupting chemicals: Implications for human health. Lancet Diabetes Endocrinol. 2020, 8, 703-718. [CrossRef]

5. Nadal, A.; Quesada, I.; Tuduri, E.; Nogueiras, R.; Alonso-Magdalena, P. Endocrine-disrupting chemicals and the regulation of energy balance. Nat. Rev. Endocrinol. 2017, 13, 536-546. [CrossRef] [PubMed]

6. Heindel, J.J.; Blumberg, B.; Cave, M.; Machtinger, R.; Mantovani, A.; Mendez, M.A.; Nadal, A.; Palanza, P.; Panzica, G.; Sargis, R.; et al. Metabolism disrupting chemicals and metabolic disorders. Reprod. Toxicol. 2017, 68, 3-33. [CrossRef] [PubMed]

7. Foulds, C.E.; Trevino, L.S.; York, B.; Walker, C.L. Endocrine-disrupting chemicals and fatty liver disease. Nat. Rev. Endocrinol. 2017, 13, 445-457. [CrossRef] [PubMed]

8. Toporova, L.; Balaguer, P. Nuclear receptors are the major targets of endocrine disrupting chemicals. Mol. Cell Endocrinol. 2020, 502, 110665. [CrossRef]

9. Kassotis, C.D.; Stapleton, H.M. Endocrine-Mediated Mechanisms of Metabolic Disruption and New Approaches to Examine the Public Health Threat. Front. Endocrinol. (Lausanne) 2019, 10, 39. [CrossRef]

10. Sonoda, J.; Pei, L.; Evans, R.M. Nuclear receptors: Decoding metabolic disease. Febs Lett. 2008, 582, 2-9. [CrossRef]

11. DeKeyser, J.G.; Laurenzana, E.M.; Peterson, E.C.; Chen, T.; Omiecinski, C.J. Selective phthalate activation of naturally occurring human constitutive androstane receptor splice variants and the pregnane $\mathrm{X}$ receptor. Toxicol. Sci. 2011, 120, 381-391. [CrossRef]

12. Dring, A.M.; Anderson, L.E.; Qamar, S.; Stoner, M.A. Rational quantitative structure-activity relationship (RQSAR) screen for PXR and CAR isoform-specific nuclear receptor ligands. Chem. Biol. Interact. 2010, 188, 512-525. [CrossRef] [PubMed]

13. Hernandez, J.P.; Mota, L.C.; Huang, W.; Moore, D.D.; Baldwin, W.S. Sexually dimorphic regulation and induction of P450s by the constitutive androstane receptor (CAR). Toxicology 2009, 256, 53-64. [CrossRef] [PubMed]

14. Mota, L.C.; Barfield, C.; Hernandez, J.P.; Baldwin, W.S. Nonylphenol-mediated CYP induction is PXR-dependent: The use of humanized mice and human hepatocytes suggests that $\mathrm{hPXR}$ is less sensitive than mouse PXR to nonylphenol treatment. Toxicol. Appl. Pharm. 2011, 252, 259-267. [CrossRef] [PubMed] 
15. Ji, X.; Li, N.; Yuan, S.; Zhou, X.; Ding, F.; Rao, K.; Ma, M.; Wang, Z. A comparison of endocrine disruption potential of nonylphenol ethoxylate, vanillin ethoxylate, 4-n-nonylphenol and vanillin in vitro. Ecotoxicol. Environ. Saf. 2019, 175, 208-214. [CrossRef]

16. Kojima, H.; Takeuchi, S.; Sanoh, S.; Okuda, K.; Kitamura, S.; Uramaru, N.; Sugihara, K.; Yoshinari, K. Profiling of bisphenol A and eight its analogues on transcriptional activity via human nuclear receptors. Toxicology 2019, 413, 48-55. [CrossRef]

17. Grimaldi, M.; Boulahtouf, A.; Toporova, L.; Balaguer, P. Functional profiling of bisphenols for nuclear receptors. Toxicology 2019, 420, 39-45. [CrossRef]

18. Gao, P.; Wang, L.; Yang, N.; Wen, J.; Zhao, M.; Su, G.; Zhang, J.; Weng, D. Peroxisome proliferator-activated receptor gamma (PPARgamma) activation and metabolism disturbance induced by bisphenol A and its replacement analog bisphenol S using in vitro macrophages and in vivo mouse models. Environ. Int. 2020, 134, 105328. [CrossRef]

19. Riu, A.; Grimaldi, M.; le Maire, A.; Bey, G.; Phillips, K.; Boulahtouf, A.; Perdu, E.; Zalko, D.; Bourguet, W.; Balaguer, P. Peroxisome proliferator-activated receptor gamma is a target for halogenated analogs of bisphenol A. Environ. Health Perspect. 2011, 119, 1227-1232. [CrossRef]

20. Ji, H.; Song, N.; Ren, J.; Li, W.; Xu, B.; Li, H.; Shen, G. Metabonomics reveals bisphenol A affects fatty acid and glucose metabolism through activation of LXR in the liver of male mice. Sci. Total Environ. 2020, 703, 134681. [CrossRef]

21. Moriyama, K.; Tagami, T.; Akamizu, T.; Usui, T.; Saijo, M.; Kanamoto, N.; Hataya, Y.; Shimatsu, A.; Kuzuya, H.; Nakao, K. Thyroid hormone action is disrupted by bisphenol A as an antagonist. J. Clin. Endocrinol. Metab. 2002, 87, 5185-5190. [CrossRef]

22. Oliveira, K.J.; Chiamolera, M.I.; Giannocco, G.; Pazos-Moura, C.C.; Ortiga-Carvalho, T.M. Thyroid Function Disruptors: From nature to chemicals. J. Mol. Endocrinol. 2018, 62. [CrossRef]

23. Laurenzana, E.M.; Coslo, D.M.; Vigilar, M.V.; Roman, A.M.; Omiecinski, C.J. Activation of the Constitutive Androstane Receptor by Monophthalates. Chem. Res. Toxicol. 2016, 29, 1651-1661. [CrossRef]

24. Wyde, M.E.; Kirwan, S.E.; Zhang, F.; Laughter, A.; Hoffman, H.B.; Bartolucci-Page, E.; Gaido, K.W.; Yan, B.; You, L. Di-n-butyl phthalate activates constitutive androstane receptor and pregnane $\mathrm{X}$ receptor and enhances the expression of steroid-metabolizing enzymes in the liver of rat fetuses. Toxicol. Sci. 2005, 86, 281-290. [CrossRef] [PubMed]

25. Zhang, H.; Zhang, Z.; Nakanishi, T.; Wan, Y.; Hiromori, Y.; Nagase, H.; Hu, J. Structure-dependent activity of phthalate esters and phthalate monoesters binding to human constitutive androstane receptor. Chem. Res. Toxicol. 2015, 28, 1196-1204. [CrossRef]

26. Mozzicafreddo, M.; Cuccioloni, M.; Bonfili, L.; Cecarini, V.; Palermo, F.A.; Cocci, P.; Mosconi, G.; Capone, A.; Ricci, I.; Eleuteri, A.M.; et al. Environmental pollutants directly affect the liver X receptor alpha activity: Kinetic and thermodynamic characterization of binding. J. Steroid Biochem. Mol. Biol. 2015, 152, 1-7. [CrossRef] [PubMed]

27. Yu, Z.; Han, Y.; Shen, R.; Huang, K.; Xu, Y.Y.; Wang, Q.N.; Zhou, S.S.; Xu, D.X.; Tao, F.B. Gestational di-(2ethylhexyl) phthalate exposure causes fetal intrauterine growth restriction through disturbing placental thyroid hormone receptor signaling. Toxicol. Lett. 2018, 294, 1-10. [CrossRef] [PubMed]

28. Abe, T.; Takahashi, M.; Kano, M.; Amaike, Y.; Ishii, C.; Maeda, K.; Kudoh, Y.; Morishita, T.; Hosaka, T.; Sasaki, T.; et al. Activation of nuclear receptor CAR by an environmental pollutant perfluorooctanoic acid. Arch. Toxicol. 2017, 91, 2365-2374. [CrossRef] [PubMed]

29. Zhang, L.; Ren, X.M.; Wan, B.; Guo, L.H. Structure-dependent binding and activation of perfluorinated compounds on human peroxisome proliferator-activated receptor gamma. Toxicol. Appl. Pharm. 2014, 279, 275-283. [CrossRef]

30. Takacs, M.L.; Abbott, B.D. Activation of mouse and human peroxisome proliferator-activated receptors (alpha, beta/delta, gamma) by perfluorooctanoic acid and perfluorooctane sulfonate. Toxicol. Sci. 2007, 95, 108-117. [CrossRef]

31. Sueyoshi, T.; Li, L.; Wang, H.; Moore, R.; Kodavanti, P.R.; Lehmler, H.J.; Negishi, M.; Birnbaum, L.S. Flame retardant BDE-47 effectively activates nuclear receptor CAR in human primary hepatocytes. Toxicol. Sci. 2014, 137, 292-302. [CrossRef] 
32. Krumm, E.A.; Patel, V.J.; Tillery, T.S.; Yasrebi, A.; Shen, J.; Guo, G.L.; Marco, S.M.; Buckley, B.T.; Roepke, T.A. Organophosphate Flame-Retardants Alter Adult Mouse Homeostasis and Gene Expression in a Sex-Dependent Manner Potentially Through Interactions With ERalpha. Toxicol. Sci. 2018, 162, 212-224. [CrossRef] [PubMed]

33. Sun, Y.; Wang, Y.; Liang, B.; Chen, T.; Zheng, D.; Zhao, X.; Jing, L.; Zhou, X.; Sun, Z.; Shi, Z. Hepatotoxicity of decabromodiphenyl ethane (DBDPE) and decabromodiphenyl ether (BDE-209) in 28-day exposed Sprague-Dawley rats. Sci. Total Environ. 2020, 705, 135783. [CrossRef]

34. Belcher, S.M.; Cookman, C.J.; Patisaul, H.B.; Stapleton, H.M. In vitro assessment of human nuclear hormone receptor activity and cytotoxicity of the flame retardant mixture FM 550 and its triarylphosphate and brominated components. Toxicol. Lett. 2014, 228, 93-102. [CrossRef]

35. Wang, Y.; Kwon, G.; An, L.; Holmes, C.N.; Haeba, M.; LeBlanc, G.A. Differential interactions of the flame retardant triphenyl phosphate within the PPAR signaling network. Moj Toxicol. 2016, 2, 67-71.

36. Ibhazehiebo, K.; Iwasaki, T.; Kimura-Kuroda, J.; Miyazaki, W.; Shimokawa, N.; Koibuchi, N. Disruption of thyroid hormone receptor-mediated transcription and thyroid hormone-induced Purkinje cell dendrite arborization by polybrominated diphenyl ethers. Environ. Health Perspect. 2011, 119, 168-175. [CrossRef]

37. Zhang, Q.; Ji, C.; Yin, X.; Yan, L.; Lu, M.; Zhao, M. Thyroid hormone-disrupting activity and ecological risk assessment of phosphorus-containing flame retardants by in vitro, in vivo and in silico approaches. Environ. Pollut. 2016, 210, 27-33. [CrossRef]

38. Cao, L.Y.; Ren, X.M.; Li, C.H.; Guo, L.H. Organophosphate Esters Bind to and Inhibit Estrogen-Related Receptor $\gamma$ in Cells. Environ. Sci. Technol. Lett. 2018, 5, 68-73. [CrossRef]

39. Bajard, L.; Melymuk, L.; Blaha, L. Prioritization of hazards of novel flame retardants using the mechanistic toxicology information from ToxCast and Adverse Outcome Pathways. Environ. Sci. Eur. 2019, 31, 14. [CrossRef]

40. Al-Salman, F.; Plant, N. Non-coplanar polychlorinated biphenyls (PCBs) are direct agonists for the human pregnane- $X$ receptor and constitutive androstane receptor, and activate target gene expression in a tissue-specific manner. Toxicol. Appl. Pharm. 2012, 263, 7-13. [CrossRef] [PubMed]

41. Gahrs, M.; Roos, R.; Andersson, P.L.; Schrenk, D. Role of the nuclear xenobiotic receptors CAR and PXR in induction of cytochromes $\mathrm{P} 450$ by non-dioxinlike polychlorinated biphenyls in cultured rat hepatocytes. Toxicol. Appl. Pharm. 2013, 272,77-85. [CrossRef]

42. Miyazaki, W.; Iwasaki, T.; Takeshita, A.; Tohyama, C.; Koibuchi, N. Identification of the functional domain of thyroid hormone receptor responsible for polychlorinated biphenyl-mediated suppression of its action in vitro. Environ. Health Perspect. 2008, 116, 1231-1236. [CrossRef] [PubMed]

43. Zhang, J.; Yang, Y.; Liu, W.; Schlenk, D.; Liu, J. Glucocorticoid and mineralocorticoid receptors and corticosteroid homeostasis are potential targets for endocrine-disrupting chemicals. Environ. Int. 2019, 133, 105133. [CrossRef] [PubMed]

44. Abass, K.; Lamsa, V.; Reponen, P.; Kublbeck, J.; Honkakoski, P.; Mattila, S.; Pelkonen, O.; Hakkola, J. Characterization of human cytochrome P450 induction by pesticides. Toxicology 2012, 294, 17-26. [CrossRef] [PubMed]

45. Casabar, R.C.; Das, P.C.; Dekrey, G.K.; Gardiner, C.S.; Cao, Y.; Rose, R.L.; Wallace, A.D. Endosulfan induces CYP2B6 and CYP3A4 by activating the pregnane X receptor. Toxicol. Appl. Pharm. 2010, 245, 335-343. [CrossRef]

46. Lemaire, G.; de Sousa, G.; Rahmani, R. A PXR reporter gene assay in a stable cell culture system: CYP3A4 and CYP2B6 induction by pesticides. Biochem. Pharm. 2004, 68, 2347-2358. [CrossRef]

47. Fujino, C.; Watanabe, Y.; Sanoh, S.; Nakajima, H.; Uramaru, N.; Kojima, H.; Yoshinari, K.; Ohta, S.; Kitamura, S. Activation of PXR, CAR and PPARalpha by pyrethroid pesticides and the effect of metabolism by rat liver microsomes. Heliyon 2019, 5, e02466. [CrossRef]

48. Takeuchi, S.; Matsuda, T.; Kobayashi, S.; Takahashi, T.; Kojima, H. In vitro screening of 200 pesticides for agonistic activity via mouse peroxisome proliferator-activated receptor (PPAR)alpha and PPARgamma and quantitative analysis of in vivo induction pathway. Toxicol. Appl. Pharm. 2006, 217, 235-244. [CrossRef]

49. Du, G.; Shen, O.; Sun, H.; Fei, J.; Lu, C.; Song, L.; Xia, Y.; Wang, S.; Wang, X. Assessing hormone receptor activities of pyrethroid insecticides and their metabolites in reporter gene assays. Toxicol. Sci. 2010, 116, 58-66. [CrossRef]

50. Yang, C.; Chen, S. Two organochlorine pesticides, toxaphene and chlordane, are antagonists for estrogen-related receptor alpha-1 orphan receptor. Cancer Res. 1999, 59, 4519-4524. 
51. Patel, R.P.; Barnes, S. Isoflavones and PPAR Signaling: A Critical Target in Cardiovascular, Metastatic, and Metabolic Disease. Ppar Res. 2010, 2010, 153252. [CrossRef]

52. Lemaire, G.; Balaguer, P.; Michel, S.; Rahmani, R. Activation of retinoic acid receptor-dependent transcription by organochlorine pesticides. Toxicol. Appl. Pharm. 2005, 202, 38-49. [CrossRef] [PubMed]

53. Zhang, J.; Zhang, J.; Liu, R.; Gan, J.; Liu, J.; Liu, W. Endocrine-Disrupting Effects of Pesticides through Interference with Human Glucocorticoid Receptor. Environ. Sci. Technol. 2016, 50, 435-443. [CrossRef] [PubMed]

54. Zhang, J.; Huang, X.; Liu, H.; Liu, W.; Liu, J. Novel Pathways of Endocrine Disruption Through Pesticides Interference with Human Mineralocorticoid Receptors. Toxicol. Sci. 2018, 162, 53-63. [CrossRef] [PubMed]

55. Marx-Stoelting, P.; Knebel, C.; Braeuning, A. The Connection of Azole Fungicides with Xeno-Sensing Nuclear Receptors, Drug Metabolism and Hepatotoxicity. Cells 2020, 9, 1192. [CrossRef]

56. Knebel, C.; Neeb, J.; Zahn, E.; Schmidt, F.; Carazo, A.; Holas, O.; Pavek, P.; Puschel, G.P.; Zanger, U.M.; Sussmuth, R.; et al. Unexpected Effects of Propiconazole, Tebuconazole, and Their Mixture on the Receptors CAR and PXR in Human Liver Cells. Toxicol. Sci. 2018, 163, 170-181. [CrossRef] [PubMed]

57. Oshida, K.; Vasani, N.; Jones, C.; Moore, T.; Hester, S.; Nesnow, S.; Auerbach, S.; Geter, D.R.; Aleksunes, L.M.; Thomas, R.S.; et al. Identification of chemical modulators of the constitutive activated receptor (CAR) in a gene expression compendium. Nucl. Recept. Signal. 2015, 13, e002. [CrossRef]

58. Dvorak, Z. Drug-drug interactions by azole antifungals: Beyond a dogma of CYP3A4 enzyme activity inhibition. Toxicol. Lett. 2011, 202, 129-132. [CrossRef] [PubMed]

59. Molina-Molina, J.M.; Hillenweck, A.; Jouanin, I.; Zalko, D.; Cravedi, J.P.; Fernandez, M.F.; Pillon, A.; Nicolas, J.C.; Olea, N.; Balaguer, P. Steroid receptor profiling of vinclozolin and its primary metabolites. Toxicol. Appl. Pharm. 2006, 216, 44-54. [CrossRef]

60. Fujino, C.; Watanabe, Y.; Sanoh, S.; Hattori, S.; Nakajima, H.; Uramaru, N.; Kojima, H.; Yoshinari, K.; Ohta, S.; Kitamura, S. Comparative study of the effect of 17 parabens on PXR-, CAR- and PPARalpha-mediated transcriptional activation. Food Chem. Toxicol. 2019, 133, 110792. [CrossRef]

61. Hu, P.; Chen, X.; Whitener, R.J.; Boder, E.T.; Jones, J.O.; Porollo, A.; Chen, J.; Zhao, L. Effects of parabens on adipocyte differentiation. ToxicolSci. 2013, 131, 56-70. [CrossRef]

62. Paul, K.B.; Thompson, J.T.; Simmons, S.O.; Vanden Heuvel, J.P.; Crofton, K.M. Evidence for triclosan-induced activation of human and rodent xenobiotic nuclear receptors. Toxicol. Vitr. 2013, 27, 2049-2060. [CrossRef]

63. Wu, Y.; Wu, Q.; Beland, F.A.; Ge, P.; Manjanatha, M.G.; Fang, J.L. Differential effects of triclosan on the activation of mouse and human peroxisome proliferator-activated receptor alpha. Toxicol. Lett. 2014, 231, 17-28. [CrossRef] [PubMed]

64. Tang, Y.; Vanlandingham, M.M.; Wu, Y.; Beland, F.A.; Olson, G.R.; Fang, J.L. Role of peroxisome proliferator-activated receptor alpha (PPARalpha) and PPARalpha-mediated species differences in triclosan-induced liver toxicity. Arch. Toxicol. 2018, 92, 3391-3402. [CrossRef]

65. Huang, W.; Zhang, J.; Moore, D.D. A traditional herbal medicine enhances bilirubin clearance by activating the nuclear receptor CAR. J. Clin. Invest. 2004, 113, 137-143. [CrossRef]

66. Lynch, C.; Zhao, J.; Huang, R.; Xiao, J.; Li, L.; Heyward, S.; Xia, M.; Wang, H. Quantitative high-throughput identification of drugs as modulators of human constitutive androstane receptor. Sci. Rep. 2015, 5, 10405. [CrossRef]

67. Kittayaruksakul, S.; Zhao, W.; Xu, M.; Ren, S.; Lu, J.; Wang, J.; Downes, M.; Evans, R.M.; Venkataramanan, R.; Chatsudthipong, V.; et al. Identification of three novel natural product compounds that activate PXR and CAR and inhibit inflammation. Pharm. Res. 2013, 30, 2199-2208. [CrossRef]

68. Wang, L.; Li, F.; Lu, J.; Li, G.; Li, D.; Zhong, X.B.; Guo, G.L.; Ma, X. The Chinese herbal medicine Sophora flavescens activates pregnane $X$ receptor. Drug Metab. Dispos. 2010, 38, 2226-2231. [CrossRef]

69. Hall, J.M.; Powell, H.A.; Rajic, L.; Korach, K.S. The Role of Dietary Phytoestrogens and the Nuclear Receptor PPARgamma in Adipogenesis: An in Vitro Study. Environ. Health Perspect. 2019, 127, 37007. [CrossRef] [PubMed]

70. Fouache, A.; Zabaiou, N.; De Joussineau, C.; Morel, L.; Silvente-Poirot, S.; Namsi, A.; Lizard, G.; Poirot, M.; Makishima, M.; Baron, S.; et al. Flavonoids differentially modulate liver X receptors activity-Structure-function relationship analysis. J. Steroid Biochem. Mol. Biol. 2019, 190, 173-182. [CrossRef]

71. Suetsugi, M.; Su, L.; Karlsberg, K.; Yuan, Y.C.; Chen, S. Flavone and isoflavone phytoestrogens are agonists of estrogen-related receptors. Mol. Cancer Res. 2003, 1, 981-991. 
72. Molnar, F.; Kublbeck, J.; Jyrkkarinne, J.; Prantner, V.; Honkakoski, P. An update on the constitutive androstane receptor (CAR). Drug Metab. Drug Interact. 2013, 28, 79-93. [CrossRef] [PubMed]

73. Kobayashi, K.; Hashimoto, M.; Honkakoski, P.; Negishi, M. Regulation of gene expression by CAR: An update. Arch. Toxicol. 2015, 89, 1045-1055. [CrossRef] [PubMed]

74. Amacher, D.E. The regulation of human hepatic drug transporter expression by activation of xenobiotic-sensing nuclear receptors. Expert Opin. Drug Metab. Toxicol. 2016, 12, 1463-1477. [CrossRef] [PubMed]

75. Mackowiak, B.; Hodge, J.; Stern, S.; Wang, H. The Roles of Xenobiotic Receptors: Beyond Chemical Disposition. Drug Metab. Dispos. 2018, 46, 1361-1371. [CrossRef] [PubMed]

76. Chai, S.C.; Lin, W.; Li, Y.; Chen, T. Drug discovery technologies to identify and characterize modulators of the pregnane $X$ receptor and the constitutive androstane receptor. Drug Discov. Today 2019, 24, 906-915. [CrossRef]

77. Negishi, M.; Kobayashi, K.; Sakuma, T.; Sueyoshi, T. Nuclear receptor phosphorylation in xenobiotic signal transduction. J. Biol. Chem. 2020. [CrossRef]

78. Mbatchi, L.C.; Brouillet, J.P.; Evrard, A. Genetic variations of the xenoreceptors NR1I2 and NR1I3 and their effect on drug disposition and response variability. Pharmacogenomics 2018, 19, 61-77. [CrossRef]

79. Baes, M.; Gulick, T.; Choi, H.S.; Martinoli, M.G.; Simha, D.; Moore, D.D. A new orphan member of the nuclear hormone receptor superfamily that interacts with a subset of retinoic acid response elements. Mol. Cell Biol. 1994, 14, 1544-1552. [CrossRef]

80. Honkakoski, P.; Moore, R.; Washburn, K.A.; Negishi, M. Activation by diverse xenochemicals of the 51-base pair phenobarbital-responsive enhancer module in the CYP2B10 gene. Mol. Pharm. 1998, 53, 597-601. [CrossRef]

81. Honkakoski, P.; Zelko, I.; Sueyoshi, T.; Negishi, M. The nuclear orphan receptor CAR-retinoid X receptor heterodimer activates the phenobarbital-responsive enhancer module of the CYP2B gene. Mol. Cell Biol. 1998, 18, 5652-5658. [CrossRef]

82. Kawamoto, T.; Sueyoshi, T.; Zelko, I.; Moore, R.; Washburn, K.; Negishi, M. Phenobarbital-responsive nuclear translocation of the receptor CAR in induction of the CYP2B gene. Mol. Cell Biol. 1999, 19, 6318-6322. [CrossRef] [PubMed]

83. Timsit, Y.E.; Negishi, M. Coordinated regulation of nuclear receptor CAR by CCRP/DNAJC7, HSP70 and the ubiquitin-proteasome system. PLoS ONE 2014, 9, e96092. [CrossRef] [PubMed]

84. Mutoh, S.; Sobhany, M.; Moore, R.; Perera, L.; Pedersen, L.; Sueyoshi, T.; Negishi, M. Phenobarbital indirectly activates the constitutive active androstane receptor (CAR) by inhibition of epidermal growth factor receptor signaling. Sci. Signal. 2013, 6, ra31. [CrossRef] [PubMed]

85. Negishi, M. Phenobarbital Meets Phosphorylation of Nuclear Receptors. Drug Metab. Dispos. 2017, 45, 532-539. [CrossRef]

86. Wei, P.; Zhang, J.; Egan-Hafley, M.; Liang, S.; Moore, D.D. The nuclear receptor CAR mediates specific xenobiotic induction of drug metabolism. Nature 2000, 407, 920-923. [CrossRef]

87. Lake, B.G. Human relevance of rodent liver tumour formation by constitutive androstane receptor (CAR) activators. Toxicol. Res. 2018, 7, 697-717. [CrossRef]

88. Kublbeck, J.; Zancanella, V.; Prantner, V.; Molnar, F.; Squires, E.J.; Dacasto, M.; Honkakoski, P.; Giantin, M. Characterization of ligand-dependent activation of bovine and pig constitutive androstane (CAR) and pregnane $X$ receptors (PXR) with interspecies comparisons. Xenobiotica 2016, 46, 200-210. [CrossRef]

89. Omiecinski, C.J.; Coslo, D.M.; Chen, T.; Laurenzana, E.M.; Peffer, R.C. Multi-species analyses of direct activators of the constitutive androstane receptor. Toxicol. Sci. 2011, 123, 550-562. [CrossRef]

90. Haines, C.; Elcombe, B.M.; Chatham, L.R.; Vardy, A.; Higgins, L.G.; Elcombe, C.R.; Lake, B.G. Comparison of the effects of sodium phenobarbital in wild type and humanized constitutive androstane receptor (CAR)/pregnane $X$ receptor (PXR) mice and in cultured mouse, rat and human hepatocytes. Toxicology 2018, 396-397, 23-32.

91. Jyrkkarinne, J.; Windshugel, B.; Makinen, J.; Ylisirnio, M.; Perakyla, M.; Poso, A.; Sippl, W.; Honkakoski, P. Amino acids important for ligand specificity of the human constitutive androstane receptor. J. Biol. Chem. 2005, 280, 5960-5971. [CrossRef] 
92. Kublbeck, J.; Jyrkkarinne, J.; Molnar, F.; Kuningas, T.; Patel, J.; Windshugel, B.; Nevalainen, T.; Laitinen, T.; Sippl, W.; Poso, A.; et al. New in vitro tools to study human constitutive androstane receptor (CAR) biology: Discovery and comparison of human CAR inverse agonists. Mol. Pharm. 2011, 8, 2424-2433. [CrossRef]

93. Cherian, M.T.; Lin, W.; Wu, J.; Chen, T. CINPA1 is an inhibitor of constitutive androstane receptor that does not activate pregnane X receptor. Mol. Pharm. 2015, 87, 878-889. [CrossRef]

94. Lynch, C.; Mackowiak, B.; Huang, R.; Li, L.; Heyward, S.; Sakamuru, S.; Wang, H.; Xia, M. Identification of Modulators That Activate the Constitutive Androstane Receptor From the Tox21 10K Compound Library. Toxicol. Sci. 2019, 167, 282-292. [CrossRef]

95. Mackowiak, B.; Wang, H. Mechanisms of xenobiotic receptor activation: Direct vs. indirect. Biochim. Biophys. Acta 2016, 1859, 1130-1140. [CrossRef] [PubMed]

96. Moore, L.B.; Parks, D.J.; Jones, S.A.; Bledsoe, R.K.; Consler, T.G.; Stimmel, J.B.; Goodwin, B.; Liddle, C.; Blanchard, S.G.; Willson, T.M.; et al. Orphan nuclear receptors constitutive androstane receptor and pregnane $X$ receptor share xenobiotic and steroid ligands. J. Biol. Chem. 2000, 275, 15122-15127. [CrossRef] [PubMed]

97. Saito, K.; Kobayashi, K.; Mizuno, Y.; Fukuchi, Y.; Furihata, T.; Chiba, K. Peroxisome proliferator-activated receptor alpha (PPARalpha) agonists induce constitutive androstane receptor (CAR) and cytochrome P450 2B in rat primary hepatocytes. Drug Metab. Pharm. 2010, 25, 108-111. [CrossRef]

98. Makinen, J.; Frank, C.; Jyrkkarinne, J.; Gynther, J.; Carlberg, C.; Honkakoski, P. Modulation of mouse and human phenobarbital-responsive enhancer module by nuclear receptors. Mol. Pharm. 2002, 62, 366-378. [CrossRef] [PubMed]

99. Miao, J.; Fang, S.; Bae, Y.; Kemper, J.K. Functional inhibitory cross-talk between constitutive androstane receptor and hepatic nuclear factor-4 in hepatic lipid/glucose metabolism is mediated by competition for binding to the DR1 motif and to the common coactivators, GRIP-1 and PGC-1alpha. J. Biol. Chem. 2006, 281, 14537-14546. [CrossRef]

100. Hardesty, J.E.; Al-Eryani, L.; Wahlang, B.; Falkner, K.C.; Shi, H.; Jin, J.; Vivace, B.J.; Ceresa, B.P.; Prough, R.A.; Cave, M.C. Epidermal Growth Factor Receptor Signaling Disruption by Endocrine and Metabolic Disrupting Chemicals. Toxicol. Sci. 2018, 162, 622-634. [CrossRef]

101. Yasujima, T.; Saito, K.; Moore, R.; Negishi, M. Phenobarbital and Insulin Reciprocate Activation of the Nuclear Receptor Constitutive Androstane Receptor through the Insulin Receptor. J. Pharm. Exp. 2016, 357, 367-374. [CrossRef]

102. Finkelstein, D.; Lamba, V.; Assem, M.; Rengelshausen, J.; Yasuda, K.; Strom, S.; Schuetz, E. ADME transcriptome in Hispanic versus White donor livers: Evidence of a globally enhanced NR1I3 (CAR, constitutive androstane receptor) gene signature in Hispanics. Xenobiotica 2006, 36, 989-1012. [CrossRef]

103. Ding, X.; Lichti, K.; Kim, I.; Gonzalez, F.J.; Staudinger, J.L. Regulation of constitutive androstane receptor and its target genes by fasting, cAMP, hepatocyte nuclear factor alpha, and the coactivator peroxisome proliferator-activated receptor gamma coactivator-1alpha. J. Biol. Chem. 2006, 281, 26540-26551. [CrossRef] [PubMed]

104. Kettner, N.M.; Voicu, H.; Finegold, M.J.; Coarfa, C.; Sreekumar, A.; Putluri, N.; Katchy, C.A.; Lee, C.; Moore, D.D.; Fu, L. Circadian Homeostasis of Liver Metabolism Suppresses Hepatocarcinogenesis. Cancer Cell 2016, 30, 909-924. [CrossRef] [PubMed]

105. Ueda, A.; Hamadeh, H.K.; Webb, H.K.; Yamamoto, Y.; Sueyoshi, T.; Afshari, C.A.; Lehmann, J.M.; Negishi, M. Diverse roles of the nuclear orphan receptor CAR in regulating hepatic genes in response to phenobarbital. Mol. Pharm. 2002, 61,1-6. [CrossRef]

106. Wallace, K.B.; Kissling, G.E.; Melnick, R.L.; Blystone, C.R. Structure-activity relationships for perfluoroalkane-induced in vitro interference with rat liver mitochondrial respiration. Toxicol. Lett. 2013, 222, 257-264. [CrossRef] [PubMed]

107. Roques, B.B.; Leghait, J.; Lacroix, M.Z.; Lasserre, F.; Pineau, T.; Viguie, C.; Martin, P.G. The nuclear receptors pregnane $X$ receptor and constitutive androstane receptor contribute to the impact of fipronil on hepatic gene expression linked to thyroid hormone metabolism. Biochem. Pharm. 2013, 86, 997-1039. [CrossRef]

108. Rouquie, D.; Tinwell, H.; Blanck, O.; Schorsch, F.; Geter, D.; Wason, S.; Bars, R. Thyroid tumor formation in the male mouse induced by fluopyram is mediated by activation of hepatic CAR/PXR nuclear receptors. Regul. Toxicol. Pharm. 2014, 70, 673-680. [CrossRef] [PubMed] 
109. Wong, H.; Lehman-McKeeman, L.D.; Grubb, M.F.; Grossman, S.J.; Bhaskaran, V.M.; Solon, E.G.; Shen, H.S.; Gerson, R.J.; Car, B.D.; Zhao, B.; et al. Increased hepatobiliary clearance of unconjugated thyroxine determines DMP 904-induced alterations in thyroid hormone homeostasis in rats. Toxicol. Sci. 2005, 84, 232-242. [CrossRef]

110. Yu, L.; Wang, Z.; Huang, M.; Li, Y.; Zeng, K.; Lei, J.; Hu, H.; Chen, B.; Lu, J.; Xie, W.; et al. Evodia alkaloids suppress gluconeogenesis and lipogenesis by activating the constitutive androstane receptor. Biochim. Biophys. Acta 2016, 1859, 1100-1111. [CrossRef]

111. Chen, F.; Coslo, D.M.; Chen, T.; Zhang, L.; Tian, Y.; Smith, P.B.; Patterson, A.D.; Omiecinski, C.J. Metabolomic Approaches Reveal the Role of CAR in Energy Metabolism. J. Proteome Res. 2019, 18, 239-251. [CrossRef]

112. Maglich, J.M.; Watson, J.; McMillen, P.J.; Goodwin, B.; Willson, T.M.; Moore, J.T. The nuclear receptor CAR is a regulator of thyroid hormone metabolism during caloric restriction. J. Biol. Chem. 2004, 279, 19832-19838. [CrossRef]

113. Qatanani, M.; Zhang, J.; Moore, D.D. Role of the constitutive androstane receptor in xenobiotic-induced thyroid hormone metabolism. Endocrinology 2005, 146, 995-1002. [CrossRef]

114. Moreau, A.; Vilarem, M.J.; Maurel, P.; Pascussi, J.M. Xenoreceptors CAR and PXR activation and consequences on lipid metabolism, glucose homeostasis, and inflammatory response. Mol. Pharm. 2008, 5, 35-41. [CrossRef] [PubMed]

115. Dong, B.; Saha, P.K.; Huang, W.; Chen, W.; Abu-Elheiga, L.A.; Wakil, S.J.; Stevens, R.D.; Ilkayeva, O.; Newgard, C.B.; Chan, L.; et al. Activation of nuclear receptor CAR ameliorates diabetes and fatty liver disease. Proc. Natl. Acad. Sci. USA 2009, 106, 18831-18836. [CrossRef] [PubMed]

116. Adam, A.A.A.; Jongejan, A.; Moerland, P.D.; van der Mark, V.A.; Oude Elferink, R.P.; Chamuleau, R.A.F.M.; Hoekstra, R. Genome-wide expression profiling reveals increased stability and mitochondrial energy metabolism of the human liver cell line HepaRG-CAR. Cytotechnology 2020, 72, 377-395. [CrossRef] [PubMed]

117. van der Mark, V.A.; Adam, A.A.A.; Chang, J.C.; Oude Elferink, R.P.; Chamuleau, R.A.F.M.; Hoekstra, R. Overexpression of the constitutive androstane receptor and shaken 3D-culturing increase biotransformation and oxidative phosphorylation and sensitivity to mitochondrial amiodarone toxicity of HepaRG cells. Toxicol. Appl. Pharm. 2020, 399, 115055. [CrossRef] [PubMed]

118. Kodama, S.; Koike, C.; Negishi, M.; Yamamoto, Y. Nuclear receptors CAR and PXR cross talk with FOXO1 to regulate genes that encode drug-metabolizing and gluconeogenic enzymes. Mol. Cell Biol. 2004, 24,7931-7940. [CrossRef]

119. Chen, K.; Zhong, J.; Hu, L.; Li, R.; Du, Q.; Cai, J.; Li, Y.; Gao, Y.; Cui, X.; Yang, X.; et al. The Role of Xenobiotic Receptors on Hepatic Glycolipid Metabolism. Curr. Drug Metab. 2019, 20, 29-35. [CrossRef]

120. Yarushkin, A.A.; Kachaylo, E.M.; Pustylnyak, V.O. The constitutive androstane receptor activator 4-[(4R,6R)-4,6-diphenyl-1,3-dioxan-2-yl]-N,N-dimethylaniline inhibits the gluconeogenic genes PEPCK and G6Pase through the suppression of HNF4alpha and FOXO1 transcriptional activity. Br. J. Pharm. 2013, 168, 1923-1932. [CrossRef]

121. Gao, J.; Yan, J.; Xu, M.; Ren, S.; Xie, W. CAR Suppresses Hepatic Gluconeogenesis by Facilitating the Ubiquitination and Degradation of PGC1alpha. Mol. Endocrinol. 2015, 29, 1558-1570. [CrossRef]

122. Kandel, B.A.; Thomas, M.; Winter, S.; Damm, G.; Seehofer, D.; Burk, O.; Schwab, M.; Zanger, U.M. Genomewide comparison of the inducible transcriptomes of nuclear receptors CAR, PXR and PPARalpha in primary human hepatocytes. Biochim. Biophys. Acta 2016, 1859, 1218-1227. [CrossRef]

123. Gao, J.; Xie, W. Targeting xenobiotic receptors PXR and CAR for metabolic diseases. Trends Pharm. Sci. 2012, 33, 552-558. [CrossRef]

124. Lahtela, J.T.; Arranto, A.J.; Sotaniemi, E.A. Enzyme inducers improve insulin sensitivity in non-insulin-dependent diabetic subjects. Diabetes 1985, 34, 911-916. [CrossRef] [PubMed]

125. Sotaniemi, E.A.; Karvonen, I. Glucose tolerance and insulin response to glucose load before and after enzyme inducing therapy in subjects with glucose intolerance and patients with NIDDM having hyperinsulinemia or relative insulin deficiency. Diabetes Res. 1989, 11, 131-139.

126. Gao, J.; He, J.; Zhai, Y.; Wada, T.; Xie, W. The constitutive androstane receptor is an anti-obesity nuclear receptor that improves insulin sensitivity. J. Biol. Chem. 2009, 284, 25984-25992. [CrossRef] [PubMed] 
127. Yarushkin, A.A.; Kazantseva, Y.A.; Prokopyeva, E.A.; Markova, D.N.; Pustylnyak, Y.A.; Pustylnyak, V.O. Constitutive androstane receptor activation evokes the expression of glycolytic genes. Biochem. Biophys. Res. Commun. 2016, 478, 1099-1105. [CrossRef] [PubMed]

128. Wieneke, N.; Hirsch-Ernst, K.I.; Kuna, M.; Kersten, S.; Puschel, G.P. PPARalpha-dependent induction of the energy homeostasis-regulating nuclear receptor NR1i3 (CAR) in rat hepatocytes: Potential role in starvation adaptation. Febs Lett. 2007, 581, 5617-5626. [CrossRef]

129. Yan, J.; Chen, B.; Lu, J.; Xie, W. Deciphering the roles of the constitutive androstane receptor in energy metabolism. Acta Pharm. Sin. 2015, 36, 62-70. [CrossRef]

130. de Vries, E.M.; Lammers, L.A.; Achterbergh, R.; Klumpen, H.J.; Mathot, R.A.; Boelen, A.; Romijn, J.A. Fasting-Induced Changes in Hepatic P450 Mediated Drug Metabolism Are Largely Independent of the Constitutive Androstane Receptor CAR. PLOS ONE 2016, 11, e0159552. [CrossRef]

131. Cai, X.; Feng, Y.; Xu, M.; Yu, C.; Xie, W. Gadd45b is required in part for the anti-obesity effect of constitutive androstane receptor (CAR). Acta Pharm. Sin. B 2020. in Press. [CrossRef]

132. Mellor, C.L.; Steinmetz, F.P.; Cronin, M.T. The identification of nuclear receptors associated with hepatic steatosis to develop and extend adverse outcome pathways. Crit. Rev. Toxicol. 2016, 46, 138-152. [CrossRef]

133. Marmugi, A.; Lukowicz, C.; Lasserre, F.; Montagner, A.; Polizzi, A.; Ducheix, S.; Goron, A.; Gamet-Payrastre, L.; Gerbal-Chaloin, S.; Pascussi, J.M.; et al. Activation of the Constitutive Androstane Receptor induces hepatic lipogenesis and regulates Pnpla3 gene expression in a LXR-independent way. Toxicol. Appl. Pharm. 2016, 303, 90-100. [CrossRef] [PubMed]

134. Sberna, A.L.; Assem, M.; Gautier, T.; Grober, J.; Guiu, B.; Jeannin, A.; Pais de Barros, J.P.; Athias, A.; Lagrost, L.; Masson, D. Constitutive androstane receptor activation stimulates faecal bile acid excretion and reverse cholesterol transport in mice. J. Hepatol. 2011, 55, 154-161. [CrossRef]

135. Guo, G.L.; Lambert, G.; Negishi, M.; Ward, J.M.; Brewer, H.B., Jr.; Kliewer, S.A.; Gonzalez, F.J.; Sinal, C.J. Complementary roles of farnesoid $\mathrm{X}$ receptor, pregnane $\mathrm{X}$ receptor, and constitutive androstane receptor in protection against bile acid toxicity. J. Biol. Chem. 2003, 278, 45062-45071. [CrossRef] [PubMed]

136. Zhang, J.; Huang, W.; Qatanani, M.; Evans, R.M.; Moore, D.D. The constitutive androstane receptor and pregnane $X$ receptor function coordinately to prevent bile acid-induced hepatotoxicity. J. Biol. Chem. 2004, 279, 49517-49522. [CrossRef]

137. Stedman, C.A.; Liddle, C.; Coulter, S.A.; Sonoda, J.; Alvarez, J.G.; Moore, D.D.; Evans, R.M.; Downes, M. Nuclear receptors constitutive androstane receptor and pregnane $\mathrm{X}$ receptor ameliorate cholestatic liver injury. Proc. Natl. Acad. Sci. USA 2005, 102, 2063-2068. [CrossRef] [PubMed]

138. Lynch, C.; Pan, Y.; Li, L.; Heyward, S.; Moeller, T.; Swaan, P.W.; Wang, H. Activation of the constitutive androstane receptor inhibits gluconeogenesis without affecting lipogenesis or fatty acid synthesis in human hepatocytes. Toxicol. Appl. Pharm. 2014, 279, 33-42. [CrossRef]

139. Li, X.; Wang, Z.; Klaunig, J.E. Modulation of xenobiotic nuclear receptors in high-fat diet induced non-alcoholic fatty liver disease. Toxicology 2018, 410, 199-213. [CrossRef]

140. Roth, A.; Looser, R.; Kaufmann, M.; Blattler, S.M.; Rencurel, F.; Huang, W.; Moore, D.D.; Meyer, U.A. Regulatory cross-talk between drug metabolism and lipid homeostasis: Constitutive androstane receptor and pregnane $X$ receptor increase Insig-1 expression. Mol. Pharm. 2008, 73, 1282-1289. [CrossRef]

141. Maglich, J.M.; Lobe, D.C.; Moore, J.T. The nuclear receptor CAR (NR1I3) regulates serum triglyceride levels under conditions of metabolic stress. J. Lipid Res. 2009, 50, 439-445. [CrossRef]

142. Roth, A.; Looser, R.; Kaufmann, M.; Meyer, U.A. Sterol regulatory element binding protein 1 interacts with pregnane $\mathrm{X}$ receptor and constitutive androstane receptor and represses their target genes. Pharm. Genom. 2008, 18, 325-337. [CrossRef]

143. Lukowicz, C.; Ellero-Simatos, S.; Regnier, M.; Oliviero, F.; Lasserre, F.; Polizzi, A.; Montagner, A.; Smati, S.; Boudou, F.; Lenfant, F.; et al. Author Correction: Dimorphic metabolic and endocrine disorders in mice lacking the constitutive androstane receptor. Sci. Rep. 2020, 10, 4256. [CrossRef] [PubMed]

144. Lukowicz, C.; Ellero-Simatos, S.; Regnier, M.; Polizzi, A.; Lasserre, F.; Montagner, A.; Lippi, Y.; Jamin, E.L.; Martin, J.F.; Naylies, C.; et al. Metabolic Effects of a Chronic Dietary Exposure to a Low-Dose Pesticide Cocktail in Mice: Sexual Dimorphism and Role of the Constitutive Androstane Receptor. Environ. Health Perspect. 2018, 126, 067007. [CrossRef] [PubMed] 
145. Butenhoff, J.L.; Bjork, J.A.; Chang, S.C.; Ehresman, D.J.; Parker, G.A.; Das, K.; Lau, C.; Lieder, P.H.; van Otterdijk, F.M.; Wallace, K.B. Toxicological evaluation of ammonium perfluorobutyrate in rats: Twenty-eightday and ninety-day oral gavage studies. Reprod. Toxicol. 2012, 33, 513-530. [CrossRef] [PubMed]

146. Masuyama, H.; Hiramatsu, Y. Treatment with constitutive androstane receptor ligand during pregnancy prevents insulin resistance in offspring from high-fat diet-induced obese pregnant mice. Am. J. Physiol. Endocrinol. Metab. 2012, 303, E293-E300. [CrossRef]

147. Zhao, Y.; Zhang, K.; Giesy, J.P.; Hu, J. Families of nuclear receptors in vertebrate models: Characteristic and comparative toxicological perspective. Sci. Rep. 2015, 5, 8554. [CrossRef] [PubMed]

148. Repo, S.; Jyrkkarinne, J.; Pulkkinen, J.T.; Laatikainen, R.; Honkakoski, P.; Johnson, M.S. Ligand specificity of constitutive androstane receptor as probed by induced-fit docking and mutagenesis. J. Med. Chem. 2008, 51,7119-7131. [CrossRef]

149. Xiao, L.; Xie, X.; Zhai, Y. Functional crosstalk of CAR-LXR and ROR-LXR in drug metabolism and lipid metabolism. Adv. Drug Deliv. Rev. 2010, 62, 1316-1321. [CrossRef]

150. Garcia, M.; Thirouard, L.; Sedes, L.; Monrose, M.; Holota, H.; Caira, F.; Volle, D.H.; Beaudoin, C. Nuclear Receptor Metabolism of Bile Acids and Xenobiotics: A Coordinated Detoxification System with Impact on Health and Diseases. Int. J. Mol. Sci. 2018, 19, 3630. [CrossRef]

151. Huang, W.; Zhang, J.; Chua, S.S.; Qatanani, M.; Han, Y.; Granata, R.; Moore, D.D. Induction of bilirubin clearance by the constitutive androstane receptor (CAR). Proc. Natl. Acad. Sci. USA 2003, 100, 4156-4161. [CrossRef]

152. Lin, W.; Bwayi, M.; Wu, J.; Li, Y.; Chai, S.C.; Huber, A.D.; Chen, T. CITCO Directly Binds to and Activates Human Pregnane X Receptor. Mol. Pharm. 2020, 97, 180-190. [CrossRef]

153. Lind, P.M.; Lind, L. Endocrine-disrupting chemicals and risk of diabetes: An evidence-based review. Diabetologia 2018, 61, 1495-1502. [CrossRef]

154. Ribeiro, C.M.; Beserra, B.T.S.; Silva, N.G.; Lima, C.L.; Rocha, P.R.S.; Coelho, M.S.; Neves, F.A.R.; Amato, A.A. Exposure to endocrine-disrupting chemicals and anthropometric measures of obesity: A systematic review and meta-analysis. Bmj Open 2020, 10, e033509. [CrossRef]

155. Choi, J.S.; Lee, Y.J.; Kim, T.H.; Lim, H.J.; Ahn, M.Y.; Kwack, S.J.; Kang, T.S.; Park, K.L.; Lee, J.; Kim, N.D.; et al. Molecular Mechanism of Tetrabromobisphenol A (TBBPA)-induced Target Organ Toxicity in Sprague-Dawley Male Rats. Toxicol. Res. 2011, 27, 61-70. [CrossRef]

156. Ito, Y.; Nakamura, T.; Yanagiba, Y.; Ramdhan, D.H.; Yamagishi, N.; Naito, H.; Kamijima, M.; Gonzalez, F.J.; Nakajima, T. Plasticizers May Activate Human Hepatic Peroxisome Proliferator-Activated Receptor alpha Less Than That of a Mouse but May Activate Constitutive Androstane Receptor in Liver. PPAR Res. 2012, 2012, 201284. [CrossRef]

157. Radke, E.G.; Galizia, A.; Thayer, K.A.; Cooper, G.S. Phthalate exposure and metabolic effects: A systematic review of the human epidemiological evidence. Environ. Int. 2019, 132, 104768. [CrossRef]

158. Eveillard, A.; Mselli-Lakhal, L.; Mogha, A.; Lasserre, F.; Polizzi, A.; Pascussi, J.M.; Guillou, H.; Martin, P.G.; Pineau, T. Di-(2-ethylhexyl)-phthalate (DEHP) activates the constitutive androstane receptor (CAR): A novel signalling pathway sensitive to phthalates. Biochem. Pharm. 2009, 77, 1735-1746. [CrossRef]

159. Ren, H.; Vallanat, B.; Nelson, D.M.; Yeung, L.W.Y.; Guruge, K.S.; Lam, P.K.S.; Lehman-McKeeman, L.D.; Corton, J.C. Evidence for the involvement of xenobiotic-responsive nuclear receptors in transcriptional effects upon perfluoroalkyl acid exposure in diverse species. Reprod. Toxicol. 2009, 27, 266-277. [CrossRef]

160. Bjork, J.A.; Butenhoff, J.L.; Wallace, K.B. Multiplicity of nuclear receptor activation by PFOA and PFOS in primary human and rodent hepatocytes. Toxicology 2011, 288, 8-17. [CrossRef]

161. Li, X.; Wang, Z.; Klaunig, J.E. The effects of perfluorooctanoate on high fat diet induced non-alcoholic fatty liver disease in mice. Toxicology 2019, 416, 1-14. [CrossRef]

162. Cheng, X.; Klaassen, C.D. Perfluorocarboxylic acids induce cytochrome P450 enzymes in mouse liver through activation of PPAR-alpha and CAR transcription factors. Toxicol. Sci. 2008, 106, 29-36. [CrossRef]

163. Elcombe, C.R.; Elcombe, B.M.; Foster, J.R.; Farrar, D.G.; Jung, R.; Chang, S.C.; Kennedy, G.L.; Butenhoff, J.L. Hepatocellular hypertrophy and cell proliferation in Sprague-Dawley rats following dietary exposure to ammonium perfluorooctanoate occurs through increased activation of the xenosensor nuclear receptors PPARalpha and CAR/PXR. Arch. Toxicol. 2010, 84, 787-798. [CrossRef] [PubMed] 
164. Richardson, V.M.; Staskal, D.F.; Ross, D.G.; Diliberto, J.J.; DeVito, M.J.; Birnbaum, L.S. Possible mechanisms of thyroid hormone disruption in mice by BDE 47, a major polybrominated diphenyl ether congener. Toxicol. Appl. Pharm. 2008, 226, 244-250. [CrossRef] [PubMed]

165. Sanders, J.M.; Burka, L.T.; Smith, C.S.; Black, W.; James, R.; Cunningham, M.L. Differential expression of CYP1A, 2B, and 3A genes in the F344 rat following exposure to a polybrominated diphenyl ether mixture or individual components. Toxicol. Sci. 2005, 88, 127-133. [CrossRef] [PubMed]

166. van Esterik, J.C.; Verharen, H.W.; Hodemaekers, H.M.; Gremmer, E.R.; Nagarajah, B.; Kamstra, J.H.; Dolle, M.E.; Legler, J.; van der Ven, L.T. Compound- and sex-specific effects on programming of energy and immune homeostasis in adult C57BL/6JxFVB mice after perinatal TCDD and PCB 153. Toxicol. Appl. Pharm. 2015, 289, 262-275. [CrossRef]

167. Wahlang, B.; Falkner, K.C.; Gregory, B.; Ansert, D.; Young, D.; Conklin, D.J.; Bhatnagar, A.; McClain, C.J.; Cave, M. Polychlorinated biphenyl 153 is a diet-dependent obesogen that worsens nonalcoholic fatty liver disease in male C57BL6/J mice. J. Nutr. Biochem. 2013, 24, 1587-1595. [CrossRef]

168. Hardesty, J.E.; Wahlang, B.; Falkner, K.C.; Clair, H.B.; Clark, B.J.; Ceresa, B.P.; Prough, R.A.; Cave, M.C. Polychlorinated biphenyls disrupt hepatic epidermal growth factor receptor signaling. Xenobiotica 2017, 47, 807-820. [CrossRef]

169. Wahlang, B.; Prough, R.A.; Falkner, K.C.; Hardesty, J.E.; Song, M.; Clair, H.B.; Clark, B.J.; States, J.C.; Arteel, G.E.; Cave, M.C. Polychlorinated Biphenyl-Xenobiotic Nuclear Receptor Interactions Regulate Energy Metabolism, Behavior, and Inflammation in Non-alcoholic-Steatohepatitis. Toxicol. Sci. 2016, 149, 396-410. [CrossRef]

170. Marx-Stoelting, P.; Ganzenberg, K.; Knebel, C.; Schmidt, F.; Rieke, S.; Hammer, H.; Schmidt, F.; Potz, O.; Schwarz, M.; Braeuning, A. Hepatotoxic effects of cyproconazole and prochloraz in wild-type and hCAR/hPXR mice. Arch. Toxicol. 2017, 91, 2895-2907. [CrossRef]

171. Heise, T.; Schmidt, F.; Knebel, C.; Rieke, S.; Haider, W.; Pfeil, R.; Kneuer, C.; Niemann, L.; Marx-Stoelting, P. Hepatotoxic effects of (tri)azole fungicides in a broad dose range. Arch. Toxicol. 2015, 89, 2105-2117. [CrossRef]

172. Tamura, K.; Inoue, K.; Takahashi, M.; Matsuo, S.; Irie, K.; Kodama, Y.; Ozawa, S.; Nishikawa, A.; Yoshida, M. Dose-response involvement of constitutive androstane receptor in mouse liver hypertrophy induced by triazole fungicides. Toxicol. Lett. 2013, 221, 47-56. [CrossRef]

173. Peffer, R.C.; Moggs, J.G.; Pastoor, T.; Currie, R.A.; Wright, J.; Milburn, G.; Waechter, F.; Rusyn, I. Mouse liver effects of cyproconazole, a triazole fungicide: Role of the constitutive androstane receptor. Toxicol. Sci. 2007, 99, 315-325. [CrossRef] [PubMed]

174. Currie, R.A.; Peffer, R.C.; Goetz, A.K.; Omiecinski, C.J.; Goodman, J.I. Phenobarbital and propiconazole toxicogenomic profiles in mice show major similarities consistent with the key role that constitutive androstane receptor (CAR) activation plays in their mode of action. Toxicology 2014, 321, 80-88. [CrossRef] [PubMed]

175. Goetz, A.K.; Bao, W.; Ren, H.; Schmid, J.E.; Tully, D.B.; Wood, C.; Rockett, J.C.; Narotsky, M.G.; Sun, G.; Lambert, G.R.; et al. Gene expression profiling in the liver of CD-1 mice to characterize the hepatotoxicity of triazole fungicides. Toxicol. Appl. Pharm. 2006, 215, 274-284. [CrossRef] [PubMed]

176. Wang, Z.; Li, X.; Klaunig, J.E. Investigation of the mechanism of triclosan induced mouse liver tumors. Regul. Toxicol. Pharm. 2017, 86, 137-147. [CrossRef]

177. Yao, R.; Yasuoka, A.; Kamei, A.; Kitagawa, Y.; Tateishi, N.; Tsuruoka, N.; Kiso, Y.; Sueyoshi, T.; Negishi, M.; Misaka, T.; et al. Dietary flavonoids activate the constitutive androstane receptor (CAR). J. Agric. Food Chem. 2010, 58, 2168-2173. [CrossRef]

178. Yao, R.; Yasuoka, A.; Kamei, A.; Ushiama, S.; Kitagawa, Y.; Rogi, T.; Shibata, H.; Abe, K.; Misaka, T. Nuclear receptor-mediated alleviation of alcoholic fatty liver by polyphenols contained in alcoholic beverages. PLoS ONE 2014, 9, e87142. [CrossRef]

179. Baldwin, W.S.; Graham, S.E.; Shea, D.; LeBlanc, G.A. Metabolic androgenization of female Daphnia magna by the xenoestrogen 4-nonylphenol. Environ. Toxicol. Chem. 2009, 16, 1905-1911. [CrossRef]

180. Gaston, S.A.; Birnbaum, L.S.; Jackson, C.L. Synthetic Chemicals and Cardiometabolic Health Across the Life Course Among Vulnerable Populations: A Review of the Literature from 2018 to 2019. Curr. Environ. Health Rep. 2020, 7, 30-47. [CrossRef] 
181. Giulivo, M.; Lopez de Alda, M.; Capri, E.; Barcelo, D. Human exposure to endocrine disrupting compounds: Their role in reproductive systems, metabolic syndrome and breast cancer. A review. Environ. Res. 2016, 151, 251-264. [CrossRef]

182. Ariemma, F.; D’Esposito, V.; Liguoro, D.; Oriente, F.; Cabaro, S.; Liotti, A.; Cimmino, I.; Longo, M.; Beguinot, F.; Formisano, P.; et al. Low-Dose Bisphenol-A Impairs Adipogenesis and Generates Dysfunctional 3T3-L1 Adipocytes. PLoS ONE 2016, 11, e0150762. [CrossRef]

183. Somm, E.; Schwitzgebel, V.M.; Toulotte, A.; Cederroth, C.R.; Combescure, C.; Nef, S.; Aubert, M.L.; Huppi, P.S. Perinatal exposure to bisphenol a alters early adipogenesis in the rat. Environ. Health Perspect. 2009, 117, 1549-1555. [CrossRef]

184. Le Magueresse-Battistoni, B.; Multigner, L.; Beausoleil, C.; Rousselle, C. Effects of bisphenol A on metabolism and evidences of a mode of action mediated through endocrine disruption. Mol. Cell Endocrinol. 2018, 475, 74-91. [CrossRef] [PubMed]

185. Liu, X.; Sakai, H.; Nishigori, M.; Suyama, K.; Nawaji, T.; Ikeda, S.; Nishigouchi, M.; Okada, H.; Matsushima, A.; Nose, T; et al. Receptor-binding affinities of bisphenol A and its next-generation analogs for human nuclear receptors. Toxicol. Appl. Pharm. 2019, 377, 114610. [CrossRef] [PubMed]

186. Kamata, R.; Nakajima, D.; Shiraishi, F. Agonistic effects of diverse xenobiotics on the constitutive androstane receptor as detected in a recombinant yeast-cell assay. Toxicol. Vitr. 2018, 46, 335-349. [CrossRef] [PubMed]

187. Germer, S.; Piersma, A.H.; van der Ven, L.; Kamyschnikow, A.; Fery, Y.; Schmitz, H.J.; Schrenk, D. Subacute effects of the brominated flame retardants hexabromocyclododecane and tetrabromobisphenol A on hepatic cytochrome P450 levels in rats. Toxicology 2006, 218, 229-236. [CrossRef] [PubMed]

188. Casals-Casas, C.; Feige, J.N.; Desvergne, B. Interference of pollutants with PPARs: Endocrine disruption meets metabolism. Int. J. Obes. 2008, 32, S53-S61. [CrossRef]

189. Maradonna, F.; Carnevali, O. Lipid Metabolism Alteration by Endocrine Disruptors in Animal Models: An Overview. Front. Endocrinol. (Lausanne) 2018, 9, 654. [CrossRef]

190. Ren, H.; Aleksunes, L.M.; Wood, C.; Vallanat, B.; George, M.H.; Klaassen, C.D.; Corton, J.C. Characterization of peroxisome proliferator-activated receptor alpha-Independent effects of PPARalpha activators in the rodent liver: Di-(2-ethylhexyl) phthalate also activates the constitutive-activated receptor. Toxicol. Sci. 2010, 113, 45-59. [CrossRef]

191. Li, C.Y.; Cheng, S.L.; Bammler, T.K.; Cui, J.Y. Editor's Highlight: Neonatal Activation of the Xenobiotic-Sensors PXR and CAR Results in Acute and Persistent Down-regulation of PPARalpha-Signaling in Mouse Liver. Toxicol. Sci. 2016, 153, 282-302. [CrossRef]

192. Lau, C.; Butenhoff, J.L.; Rogers, J.M. The developmental toxicity of perfluoroalkyl acids and their derivatives. Toxicol. Appl. Pharm. 2004, 198, 231-241. [CrossRef]

193. Coperchini, F.; Awwad, O.; Rotondi, M.; Santini, F.; Imbriani, M.; Chiovato, L. Thyroid disruption by perfluorooctane sulfonate (PFOS) and perfluorooctanoate (PFOA). J. Endocrinol. Invest. 2017, 40, $105-121$. [CrossRef] [PubMed]

194. Foresta, C.; Tescari, S.; Di Nisio, A. Impact of perfluorochemicals on human health and reproduction: A male's perspective. J. Endocrinol. Invest. 2018, 41, 639-645. [CrossRef] [PubMed]

195. Ding, N.; Harlow, S.D.; Randolph, J.F., Jr.; Loch-Caruso, R.; Park, S.K. Perfluoroalkyl and polyfluoroalkyl substances (PFAS) and their effects on the ovary. Hum. Reprod. Update 2020, 26, 724-752. [CrossRef]

196. Lau, C.; Rumpler, J.; Das, K.P.; Wood, C.R.; Schmid, J.E.; Strynar, M.J.; Wambaugh, J.F. Pharmacokinetic profile of Perfluorobutane Sulfonate and activation of hepatic nuclear receptor target genes in mice. Toxicology 2020, 441, 152522. [CrossRef]

197. Rosen, M.B.; Das, K.P.; Rooney, J.; Abbott, B.; Lau, C.; Corton, J.C. PPARalpha-independent transcriptional targets of perfluoroalkyl acids revealed by transcript profiling. Toxicology 2017, 387, 95-107. [CrossRef]

198. Behr, A.C.; Plinsch, C.; Braeuning, A.; Buhrke, T. Activation of human nuclear receptors by perfluoroalkylated substances (PFAS). Toxicol. Vitr. 2020, 62, 104700. [CrossRef]

199. Corton, J.C.; Cunningham, M.L.; Hummer, B.T.; Lau, C.; Meek, B.; Peters, J.M.; Popp, J.A.; Rhomberg, L.; Seed, J.; Klaunig, J.E. Mode of action framework analysis for receptor-mediated toxicity: The peroxisome proliferator-activated receptor alpha (PPARalpha) as a case study. Crit. Rev. Toxicol. 2014, 44,1-49. [CrossRef] 
200. Louisse, J.; Rijkers, D.; Stoopen, G.; Janssen, A.; Staats, M.; Hoogenboom, R.; Kersten, S.; Peijnenburg, A. Perfluorooctanoic acid (PFOA), perfluorooctane sulfonic acid (PFOS), and perfluorononanoic acid (PFNA) increase triglyceride levels and decrease cholesterogenic gene expression in human HepaRG liver cells. Arch. Toxicol. 2020, 94, 3137-3155. [CrossRef]

201. Hales, B.F.; Robaire, B. Effects of brominated and organophosphate ester flame retardants on male reproduction. Andrology 2020, 8, 915-923. [CrossRef]

202. Honkakoski, P.; Palvimo, J.J.; Penttila, L.; Vepsalainen, J.; Auriola, S. Effects of triaryl phosphates on mouse and human nuclear receptors. Biochem. Pharm. 2004, 67, 97-106. [CrossRef]

203. Sakai, H.; Kim, E.Y.; Petrov, E.A.; Tanabe, S.; Iwata, H. Transactivation potencies of Baikal seal constitutive active/androstane receptor by persistent organic pollutants and brominated flame retardants. Environ. Sci. Technol. 2009, 43, 6391-6397. [CrossRef] [PubMed]

204. Lee, D.H.; Porta, M.; Jacobs, D.R., Jr.; Vandenberg, L.N. Chlorinated persistent organic pollutants, obesity, and type 2 diabetes. Endocr. Rev. 2014, 35, 557-601. [CrossRef]

205. Lee, Y.M.; Jacobs, D.R., Jr.; Lee, D.H. Persistent Organic Pollutants and Type 2 Diabetes: A Critical Review of Review Articles. Front. Endocrinol. (Lausanne) 2018, 9, 712. [CrossRef] [PubMed]

206. Kamata, R.; Shiraishi, F.; Kageyama, S.; Nakajima, D. Detection and measurement of the agonistic activities of PCBs and mono-hydroxylated PCBs to the constitutive androstane receptor using a recombinant yeast assay. Toxicol. Vitr. 2015, 29, 1859-1867. [CrossRef] [PubMed]

207. Chen, Y.; Liu, Y. Non-coplanar and coplanar polychlorinated biphenyls potentiate genotoxicity of aflatoxin B1 in a human hepatocyte line by enhancing CYP1A2 and CYP3A4 expression. Environ. Pollut. 2019, 246, 945-954. [CrossRef]

208. Dietrich, K.; Baumgart, J.; Eshkind, L.; Reuter, L.; Godtel-Armbrust, U.; Butt, E.; Musheev, M.; Marini, F.; More, P.; Grosser, T.; et al. Health-Relevant Phenotypes in the Offspring of Mice Given CAR Activators Prior to Pregnancy. Drug Metab. Dispos. 2018, 46, 1827-1835. [CrossRef]

209. Wahlang, B.; Falkner, K.C.; Clair, H.B.; Al-Eryani, L.; Prough, R.A.; States, J.C.; Coslo, D.M.; Omiecinski, C.J.; Cave, M.C. Human receptor activation by aroclor 1260, a polychlorinated biphenyl mixture. Toxicol. Sci. 2014, 140, 283-297. [CrossRef]

210. Kretschmer, X.C.; Baldwin, W.S. CAR and PXR: Xenosensors of endocrine disrupters? Chem. Biol. Interact. 2005, 155, 111-128. [CrossRef]

211. Savary, C.C.; Josse, R.; Bruyere, A.; Guillet, F.; Robin, M.A.; Guillouzo, A. Interactions of endosulfan and methoxychlor involving CYP3A4 and CYP2B6 in human HepaRG cells. Drug Metab. Dispos. 2014, 42, 1235-1240. [CrossRef]

212. Wyde, M.E.; Bartolucci, E.; Ueda, A.; Zhang, H.; Yan, B.; Negishi, M.; You, L. The environmental pollutant 1,1-dichloro-2,2-bis (p-chlorophenyl)ethylene induces rat hepatic cytochrome P450 2B and 3A expression through the constitutive androstane receptor and pregnane X receptor. Mol. Pharm. 2003, 64, 474-481. [CrossRef]

213. Kublbeck, J.; Laitinen, T.; Jyrkkarinne, J.; Rousu, T.; Tolonen, A.; Abel, T.; Kortelainen, T.; Uusitalo, J.; Korjamo, T.; Honkakoski, P.; et al. Use of comprehensive screening methods to detect selective human CAR activators. Biochem. Pharm. 2011, 82, 1994-2007. [CrossRef] [PubMed]

214. Kojima, H.; Sata, F.; Takeuchi, S.; Sueyoshi, T.; Nagai, T. Comparative study of human and mouse pregnane $\mathrm{X}$ receptor agonistic activity in 200 pesticides using in vitro reporter gene assays. Toxicology 2011, 280, 77-87. [CrossRef] [PubMed]

215. Xia, J.; Lin, J.; Li, X.N.; Zhang, C.; Li, N.; Du, Z.H.; Li, Y.H.; Li, J.L. Atrazine-induced environmental nephrosis was mitigated by lycopene via modulating nuclear xenobiotic receptors-mediated response. J. Nutr. Biochem. 2018, 51, 80-90. [CrossRef] [PubMed]

216. Petrakis, D.; Vassilopoulou, L.; Mamoulakis, C.; Psycharakis, C.; Anifantaki, A.; Sifakis, S.; Docea, A.O.; Tsiaoussis, J.; Makrigiannakis, A.; Tsatsakis, A.M. Endocrine Disruptors Leading to Obesity and Related Diseases. Int. J. Environ. Res. Public Health 2017, 14, 1282. [CrossRef] [PubMed]

217. Taxvig, C.; Vinggaard, A.M.; Hass, U.; Axelstad, M.; Metzdorff, S.; Nellemann, C. Endocrine-disrupting properties in vivo of widely used azole fungicides. Int. J. 2008, 31, 170-177. [CrossRef] [PubMed] 
218. Paul Friedman, K.; Papineni, S.; Marty, M.S.; Yi, K.D.; Goetz, A.K.; Rasoulpour, R.J.; Kwiatkowski, P.; Wolf, D.C.; Blacker, A.M.; Peffer, R.C. A predictive data-driven framework for endocrine prioritization: A triazole fungicide case study. Crit. Rev. Toxicol. 2016, 46, 785-833. [CrossRef]

219. Tamura, K.; Inoue, K.; Takahashi, M.; Matsuo, S.; Irie, K.; Kodama, Y.; Gamo, T.; Ozawa, S.; Yoshida, M. Involvement of constitutive androstane receptor in liver hypertrophy and liver tumor development induced by triazole fungicides. Food Chem. Toxicol. 2015, 78, 86-95. [CrossRef]

220. Lake, B.G.; Price, R.J.; Osimitz, T.G. Mode of action analysis for pesticide-induced rodent liver tumours involving activation of the constitutive androstane receptor: Relevance to human cancer risk. Pest. Manag. Sci. 2015, 71, 829-834. [CrossRef]

221. Skinner, M.K. Endocrine disruptors in 2015: Epigenetic transgenerational inheritance. Nat. Rev. Endocrinol. 2016, 12, 68-70. [CrossRef]

222. Shah, I.; Houck, K.; Judson, R.S.; Kavlock, R.J.; Martin, M.T.; Reif, D.M.; Wambaugh, J.; Dix, D.J. Using nuclear receptor activity to stratify hepatocarcinogens. PLoS ONE 2011, 6, e14584. [CrossRef]

223. Knebel, C.; Buhrke, T.; Sussmuth, R.; Lampen, A.; Marx-Stoelting, P.; Braeuning, A. Pregnane X receptor mediates steatotic effects of propiconazole and tebuconazole in human liver cell lines. Arch. Toxicol. 2019, 93, 1311-1322. [CrossRef] [PubMed]

224. Witorsch, R.J. Critical analysis of endocrine disruptive activity of triclosan and its relevance to human exposure through the use of personal care products. Crit. Rev. Toxicol. 2014, 44, 535-555. [CrossRef] [PubMed]

225. Braun, J.M. Early-life exposure to EDCs: Role in childhood obesity and neurodevelopment. Nat. Rev. Endocrinol. 2017, 13, 161-173. [CrossRef]

226. Yueh, M.F.; Taniguchi, K.; Chen, S.; Evans, R.M.; Hammock, B.D.; Karin, M.; Tukey, R.H. The commonly used antimicrobial additive triclosan is a liver tumor promoter. Proc. Natl. Acad. Sci. USA 2014, 111, 17200-17205. [CrossRef] [PubMed]

227. Haines, C.; Chatham, L.R.; Vardy, A.; Elcombe, C.R.; Foster, J.R.; Lake, B.G. Comparison of the hepatic and thyroid gland effects of sodium phenobarbital and pregnenolone-16alpha-carbonitrile in wild-type and constitutive androstane receptor (CAR)/pregnane X receptor (PXR) knockout rats. Xenobiotica 2019, 49, 227-238. [CrossRef]

228. Soares, A.; Guieysse, B.; Jefferson, B.; Cartmell, E.; Lester, J.N. Nonylphenol in the environment: A critical review on occurrence, fate, toxicity and treatment in wastewaters. Environ. Int. 2008, 34, 1033-1049. [CrossRef]

229. Lu, Y.F.; Jin, T.; Xu, Y.; Zhang, D.; Wu, Q.; Zhang, Y.K.; Liu, J. Sex differences in the circadian variation of cytochrome p450 genes and corresponding nuclear receptors in mouse liver. Chronobiol. Int. 2013, 30, 1135-1143. [CrossRef]

230. Lodato, N.J.; Melia, T.; Rampersaud, A.; Waxman, D.J. Sex-Differential Responses of Tumor Promotion-Associated Genes and Dysregulation of Novel Long Noncoding RNAs in Constitutive Androstane Receptor-Activated Mouse Liver. Toxicol. Sci. 2017, 159, 25-41. [CrossRef]

231. Hernandez, J.P.; Huang, W.; Chapman, L.M.; Chua, S.; Moore, D.D.; Baldwin, W.S. The environmental estrogen, nonylphenol, activates the constitutive androstane receptor. Toxicol. Sci. 2007, 98, 416-426. [CrossRef]

232. Cashman, A.L.; Warshaw, E.M. Parabens: A review of epidemiology, structure, allergenicity, and hormonal properties. Dermatitis 2005, 16, 57-66, 55-56.

233. Hipwell, A.E.; Kahn, L.G.; Factor-Litvak, P.; Porucznik, C.A.; Siegel, E.L.; Fichorova, R.N.; Hamman, R.F.; Klein-Fedyshin, M.; Harley, K.G. Program collaborators for Environmental influences on Child Health Outcomes Exposure to non-persistent chemicals in consumer products and fecundability: A systematic review. Hum. Reprod. Update 2019, 25, 51-71. [CrossRef]

234. Laakso, M.; Kuusisto, J. Diabetes Secondary to Treatment with Statins. Curr. Diab. Rep. 2017, 17. [CrossRef] [PubMed]

235. Kobayashi, K.; Yamanaka, Y.; Iwazaki, N.; Nakajo, I.; Hosokawa, M.; Negishi, M.; Chiba, K. Identification of HMG-CoA reductase inhibitors as activators for human, mouse and rat constitutive androstane receptor. Drug Metab. Dispos. 2005, 33, 924-929. [CrossRef] [PubMed] 
236. Hassani-Nezhad-Gashti, F.; Kummu, O.; Karpale, M.; Rysa, J.; Hakkola, J. Nutritional status modifies pregnane $X$ receptor regulated transcriptome. Sci. Rep. 2019, 9. [CrossRef] [PubMed]

237. Galicia-Garcia, U.; Jebari, S.; Larrea-Sebal, A.; Uribe, K.B.; Siddiqi, H.; Ostolaza, H.; Benito-Vicente, A.; Martin, C. Statin Treatment-Induced Development of Type 2 Diabetes: From Clinical Evidence to Mechanistic Insights. Int. J. Mol. Sci. 2020, 21, 4725. [CrossRef] [PubMed]

238. Chang, T.K. Activation of pregnane $X$ receptor (PXR) and constitutive androstane receptor (CAR) by herbal medicines. Aaps J. 2009, 11, 590-601. [CrossRef] [PubMed]

239. Xu, C.; Huang, M.; Bi, H. PXR- and CAR-mediated herbal effect on human diseases. Biochim. Biophys. Acta 2016, 1859, 1121-1129. [CrossRef] [PubMed]

240. Cave, M.C.; Clair, H.B.; Hardesty, J.E.; Falkner, K.C.; Feng, W.; Clark, B.J.; Sidey, J.; Shi, H.; Aqel, B.A.; McClain, C.J.; et al. Nuclear receptors and nonalcoholic fatty liver disease. Biochim. Biophys. Acta 2016, 1859, 1083-1099. [CrossRef] [PubMed]

241. Ayed-Boussema, I.; Pascussi, J.M.; Maurel, P.; Bacha, H.; Hassen, W. Zearalenone activates pregnane X receptor, constitutive androstane receptor and aryl hydrocarbon receptor and corresponding phase I target genes mRNA in primary cultures of human hepatocytes. Environ. Toxicol. Pharm. 2011, 31, 79-87. [CrossRef]

242. Carazo Fernandez, A.; Smutny, T.; Hyrsova, L.; Berka, K.; Pavek, P. Chrysin, baicalein and galangin are indirect activators of the human constitutive androstane receptor (CAR). Toxicol. Lett. 2015, 233, 68-77. [CrossRef]

243. Li, X.; Li, S.; Chen, M.; Wang, J.; Xie, B.; Sun, Z. (-)-Epigallocatechin-3-gallate (EGCG) inhibits starch digestion and improves glucose homeostasis through direct or indirect activation of PXR/CAR-mediated phase II metabolism in diabetic mice. Food Funct. 2018, 9, 4651-4663. [CrossRef] [PubMed]

244. Hoek-van den Hil, E.F.; van Schothorst, E.M.; van der Stelt, I.; Swarts, H.J.; Venema, D.; Sailer, M.; Vervoort, J.J.; Hollman, P.C.; Rietjens, I.M.; Keijer, J. Quercetin decreases high-fat diet induced body weight gain and accumulation of hepatic and circulating lipids in mice. Genes Nutr. 2014, 9, 418. [CrossRef] [PubMed]

245. Kopec, A.K.; Burgoon, L.D.; Ibrahim-Aibo, D.; Mets, B.D.; Tashiro, C.; Potter, D.; Sharratt, B.; Harkema, J.R.; Zacharewski, T.R. PCB153-elicited hepatic responses in the immature, ovariectomized C57BL/6 mice: Comparative toxicogenomic effects of dioxin and non-dioxin-like ligands. Toxicol. Appl. Pharm. 2010, 243, 359-371. [CrossRef] [PubMed]

246. Leblanc, A.F.; Attignon, E.A.; Distel, E.; Karakitsios, S.P.; Sarigiannis, D.A.; Bortoli, S.; Barouki, R.; Coumoul, X.; Aggerbeck, M.; Blanc, E.B. A dual mixture of persistent organic pollutants modifies carbohydrate metabolism in the human hepatic cell line HepaRG. Environ. Res. 2019, 178, 108628. [CrossRef]

247. Jackson, E.N.; Thatcher, S.E.; Larian, N.; English, V.; Soman, S.; Morris, A.J.; Weng, J.; Stromberg, A.; Swanson, H.I.; Pearson, K.; et al. Effects of Aryl Hydrocarbon Receptor Deficiency on PCB-77-Induced Impairment of Glucose Homeostasis during Weight Loss in Male and Female Obese Mice. Environ. Health Perspect. 2019, 127, 77004. [CrossRef] [PubMed]

248. Nault, R.; Fader, K.A.; Ammendolia, D.A.; Dornbos, P.; Potter, D.; Sharratt, B.; Kumagai, K.; Harkema, J.R.; Lunt, S.Y.; Matthews, J.; et al. Dose-Dependent Metabolic Reprogramming and Differential Gene Expression in TCDD-Elicited Hepatic Fibrosis. Toxicol. Sci. 2016, 154, 253-266. [CrossRef]

249. Prokopec, S.D.; Watson, J.D.; Lee, J.; Pohjanvirta, R.; Boutros, P.C. Sex-related differences in murine hepatic transcriptional and proteomic responses to TCDD. Toxicol. Appl. Pharm. 2015, 284, 188-196. [CrossRef]

250. Fader, K.A.; Nault, R.; Doskey, C.M.; Fling, R.R.; Zacharewski, T.R. 2,3,7,8-Tetrachlorodibenzo-p-dioxin abolishes circadian regulation of hepatic metabolic activity in mice. Sci. Rep. 2019, 9, 6514. [CrossRef]

251. Lauschke, V.M.; Shafagh, R.Z.; Hendriks, D.F.G.; Ingelman-Sundberg, M. 3D Primary Hepatocyte Culture Systems for Analyses of Liver Diseases, Drug Metabolism, and Toxicity: Emerging Culture Paradigms and Applications. Biotechnol. J. 2019, 14, e1800347. [CrossRef]

252. Hendriks, D.F.G.; Vorrink, S.U.; Smutny, T.; Sim, S.C.; Nordling, A.; Ullah, S.; Kumondai, M.; Jones, B.C.; Johansson, I.; Andersson, T.B.; et al. Clinically Relevant Cytochrome P450 3A4 Induction Mechanisms and Drug Screening in Three-Dimensional Spheroid Cultures of Primary Human Hepatocytes. Clin. Pharm. 2020, $41,24-29$. 
253. Prakash, C.; Zuniga, B.; Song, C.S.; Jiang, S.; Cropper, J.; Park, S.; Chatterjee, B. Nuclear Receptors in Drug Metabolism, Drug Response and Drug Interactions. Nucl. Recept. Res. 2015, 2. [CrossRef] [PubMed]

254. Wang, P.; Shao, X.; Bao, Y.; Zhu, J.; Chen, L.; Zhang, L.; Ma, X.; Zhong, X.B. Impact of obese levels on the hepatic expression of nuclear receptors and drug-metabolizing enzymes in adult and offspring mice. Acta Pharm. Sin. B 2020, 10, 171-185. [CrossRef]

Publisher's Note: MDPI stays neutral with regard to jurisdictional claims in published maps and institutional affiliations.

(C) 2020 by the authors. Licensee MDPI, Basel, Switzerland. This article is an open access article distributed under the terms and conditions of the Creative Commons Attribution (CC BY) license (http://creativecommons.org/licenses/by/4.0/). 